\title{
Spatiotemporal variation, sources, and secondary transformation potential of volatile organic compounds in Xi'an, China
}

\author{
Mengdi Song ${ }^{1}$, Xin $\mathrm{Li}^{1}$, Suding Yang ${ }^{1}$, Xuena Yu ${ }^{1}$, Songxiu Zhou ${ }^{1}$, Yiming Yang ${ }^{1}$, Shiyi Chen ${ }^{1}$, Huabin Dong ${ }^{1}$, \\ Keren Liao $^{1}$, Qi Chen ${ }^{1}$, Keding Lu ${ }^{1}$, Ningning Zhang ${ }^{2}$, Junji Cao ${ }^{2}$, Limin Zeng ${ }^{1}$, and Yuanhang Zhang ${ }^{1}$ \\ ${ }^{1}$ State Key Joint Laboratory of Environmental Simulation and Pollution Control, College of Environmental Sciences and \\ Engineering, Peking University, Beijing 100871, China \\ ${ }^{2}$ Key laboratory of Aerosol Chemistry and Physics, SKLLQG, Institute of Earth Environment, Chinese Academy of Science, \\ Xi'an 710061, China
}

Correspondence: Xin Li (li_xin@pku.edu.cn)

Received: 11 July 2020 - Discussion started: 27 August 2020

Revised: 21 February 2021 - Accepted: 23 February 2021 - Published: 30 March 2021

\begin{abstract}
As critical precursors of ozone $\left(\mathrm{O}_{3}\right)$ and secondary organic aerosols, volatile organic compounds (VOCs) play a vital role in air quality, human health, and climate change. In this study, a campaign of comprehensive field observations and VOC grid sampling was conducted in Xi' an, China, from 20 June to 20 July 2019 to identify the spatiotemporal concentration levels, sources, and secondary transformation potential of VOCs. During the observation period, the average VOC concentrations at the Chanba (CB), Di Huan Suo (DHS), Qinling (QL), and gridded sampling sites were $27.8 \pm 8.9,33.8 \pm 10.5,15.5 \pm 5.8$, and $29.1 \pm 8.4 \mathrm{ppb}$, respectively. Vehicle exhaust was the primary source of VOC emissions in Xi'an, and the contributions of vehicle exhaust to VOCs at the CB, DHS, and QL sites were $41.3 \%, 30.6 \%$, and $23.6 \%-41.4 \%$, respectively. While industrial emissions were the second-largest source of VOCs in urban areas, contributions from aging sources were high in rural areas. High potential source contribution function values primarily appeared in eastern and southern Xi'an near the sampling site, which indicates that Xi' an exhibits a strong local VOC source. Moreover, alkenes, aromatics, and oxygenated VOCs played a dominant role in secondary transformation, which is a major concern in reducing $\mathrm{O}_{3}$ pollution in $\mathrm{Xi}$ ' an.
\end{abstract}

\section{Introduction}

Atmospheric pollution in China is characterized by frequent secondary pollution, which is primarily reflected by the yearly increasing ozone $\left(\mathrm{O}_{3}\right)$ concentrations and proportion of secondary organic aerosol (SOA) components in $\mathrm{PM}_{2.5}$ (Lu et al., 2018; Huang et al., 2014). The increasingly severe secondary pollution has restricted improvements in Chinese ambient air quality. Volatile organic compounds (VOCs) are vital precursors of $\mathrm{O}_{3}$ and SOA, and reducing VOC emissions is crucial for controlling $\mathrm{O}_{3}$ and $\mathrm{PM}_{2.5}$ pollution (Jin and Holloway, 2015; Yuan et al., 2013).

VOC sources can be divided into biogenic and anthropogenic sources. Although the VOC emissions from biological sources are more than 10 times that of anthropogenic sources globally (Roger and Janet, 2003), anthropogenic sources often dominate the urban atmospheric environment and exert a substantial influence on the formation of $\mathrm{O}_{3}$ and SOA in the atmosphere (Ahmad et al., 2017; Cuisset et al., 2016; Schwantes et al., 2017). Anthropogenic VOC sources primarily include vehicle exhaust, industrial, paint solvent usage, combustion, and fuel evaporation sources. In recent years, the source apportionment of observation results found that the contribution of vehicle exhaust sources to VOCs plays a leading role in VOC emissions in China, reaching $22 \%-58 \%$ (Jia et al., 2016; Liu et al., 2016a, 2020; Zhang et al., 2019). However, the VOC sources exhibit clear differences in various regions. For example, paint solvent usage is the main source of VOCs in Langfang and Xiamen city 
(Zhang et al., 2019; Zhuang et al., 2019), while the primary sources of VOCs in Wuhan city are combustion and vehicle exhaust sources (Shen et al., 2020). The results of VOC emission inventory research indicate that the contribution of vehicle exhaust sources to VOC emissions is gradually decreasing, and industrial sources and paint solvent usage have become the primary sources of VOCs in China (Li et al., 2019; Wu et al., 2016b).

$\mathrm{O}_{3}$ has become one of the most important pollutants affecting the air quality of the Fenwei Plain. According to the 2018 and 2019 Report on the State of the Ecology and Environment in China released by the Ministry of Ecology and Environment of the People's Republic of China (http: //www.mee.gov.cn/, last access: 24 February 2021), the annual average evaluation value of $\mathrm{O}_{3}$ concentration in the Fenwei Plain exceeded the Chinese annual evaluation standard $\left(160 \mu \mathrm{g} / \mathrm{m}^{3}\right)$ for at least 2 consecutive years. Moreover, the average 90th percentile $\mathrm{O}_{3}$ daily maximum $8 \mathrm{~h}$ concentration in the Fenwei Plain was $171 \mu \mathrm{g} / \mathrm{m}^{3}(298.15 \mathrm{~K}, 1013.25 \mathrm{hPa})$, which was $4.2 \%$ higher than that in 2018. Xi' an, one of the most famous historic and megacities in Fenwei Plain with a quickly growing economy, has also experienced severe $\mathrm{O}_{3}$ pollution in recent years. Based on the Report on the State of the Environment in Xi'an (http://xaepb.xa.gov.cn/, last access: 24 February 2021), the average 90th percentile $\mathrm{O}_{3}$ daily maximum $8 \mathrm{~h}$ concentration in $\mathrm{Xi}$ ' an exceeded the national standards, reaching $169.5,164.9$, and $166 \mu \mathrm{g} / \mathrm{m}^{3}(298.15 \mathrm{~K}$, $1013.25 \mathrm{hPa}$ ) in 2017,2018 , and 2019, respectively. In addition, according to statistics released by the Ministry of Public Security, as of the end of 2018, the number of motor vehicles in Xi' an reached 3 million, making Xi'an one of the top eight cities in China in terms of number of motor vehicles. Considering the increasing $\mathrm{O}_{3}$ concentration and high amount of pollution in Xi' an, studies are imperative in exploring the characteristics, sources, and precursors (VOCs and $\mathrm{NO}_{x}$ ) of $\mathrm{O}_{3}$ to support the design and implementation of pollution control strategies in Xi'an.

In recent years, numerous VOC observations have been made in many regions of China, particularly in the BeijingTianjin-Hebei, Yangtze River Delta, Pearl River Delta, and Chengdu-Chongqing regions. However, there are few studies on Xi'an. Therefore, our understanding of the spatiotemporal characteristics, source contributions, and secondary transformation potential of VOCs in Xi' an remains limited. To elucidate the concentration levels, source characteristics, and secondary conversion ability of $\mathrm{O}_{3}$ precursors, we conducted comprehensive field observations and VOC grid sampling in Xi' an from 20 June to 20 July 2019 . The primary objectives of this study are to (1) determine the temporal and spatial characteristics of atmospheric VOCs in Xi'an, (2) illuminate the characteristics of VOCs during $\mathrm{O}_{3}$ pollution events, (3) identify critical precursors in Xi' an, and (4) explore VOC sources in Xi'an.

\section{Observation and methods}

\subsection{Observation campaign description}

To obtain the temporal and spatial distributions of summertime VOCs in Xi'an, a field observation and VOC grid sampling campaign was applied in this study. The field observation campaign occurred from 20 June to 20 July 2019. Based on an in-person investigation, the prevailing winds, and the electricity supply, three sites were chosen for the field observation campaign (Fig. 1): the Chanba (CB; $34^{\circ} 20^{\prime} 12^{\prime \prime} \mathrm{N}, 109^{\circ} 01^{\prime} 35^{\prime \prime} \mathrm{E}$ ), Di Huan Suo (DHS; $\left.34^{\circ} 13^{\prime} 49^{\prime \prime} \mathrm{N}, 108^{\circ} 52^{\prime} 58^{\prime \prime} \mathrm{E}\right)$, and Qinling (QL; $34^{\circ} 04^{\prime} 11^{\prime \prime} \mathrm{N}$, $108^{\circ} 20^{\prime} 31^{\prime \prime} \mathrm{E}$ ) sites, which were located on upwind, downtown, and downwind areas of Xi'an city, respectively. The $\mathrm{CB}$ site was at the national environmental air quality monitoring urban station (approximately $10 \mathrm{~m}$ above ground level) in the Baqiao District, which was close to the third ring road, one of the main traffic thoroughfares in Xi' an. The DHS site was located on the roof of a four-story building (approximately $15 \mathrm{~m}$ above ground level) at the Institute of Earth Environment, Chinese Academy of Science in the Yanta District, which was close to the second ring road. The QL site was located in Zhouzhi County, which was adjacent to the Qinling National Botanical Garden. The VOC measurement instrument used in the field observation campaign was an online gas chromatography system that was equipped with a mass spectrometer and flame ionization detector ( $\mathrm{GC}-$ MS/FID). The GC-MS/FID instrument utilized a dual gas path separation method. The sample gas, after water and $\mathrm{CO}_{2}$ were removed, captured VOC components through an ultralow temperature system $\left(-160^{\circ} \mathrm{C}\right)$, and the gas chromatography analysis system was utilized after thermal desorption. The oven temperature was programmed at $37^{\circ}$ maintained for $5 \mathrm{~min}$ initially, then raised to $120^{\circ}$ at $5^{\circ} \mathrm{min}^{-1}$ holding for $5 \mathrm{~min}$, and later raised to $180^{\circ}$ at $6^{\circ} \mathrm{min}^{-1}$ holding for $5 \mathrm{~min}$. The low carbon number $\left(\mathrm{C}_{2}-\mathrm{C}_{5}\right)$ compounds were separated on an $\mathrm{Al}_{2} \mathrm{O}_{3} / \mathrm{KCl}$ PLOT column and quantified using the FID $\left(200^{\circ}\right)$. The high carbon number $\left(\mathrm{C}_{5}-\mathrm{C}_{10}\right)$ compounds were separated on a DB-624 column and quantified using MS $\left(230^{\circ}\right)$. External and internal standard gases produced by The Linde Group in the United States were used to calibrate the GC-MS/FID. External standard gas was used to calibrate the GC-MS/FID weekly during the campaign to ensure quantitative accuracy. In addition, the instruments were also daily calibrated by internal standard gases (bromochloromethane, 1,4-dichlorobenzene, chlorobenzene, and fluorobromobenzene) to ensure the stability of the instrument. During the observation period, the GC-MS/FID was in sufficient working condition, and the square correlation coefficients of the VOCs work curves were greater than 0.99 . The method detection limits (MDLs) for each VOC compound were calculated according to the TO-15 standard of the United States Environmental Protection Agency (EPA) (Liu et al., 2008b), and the MDL for all measured VOC com- 
pounds in this study ranged from 0.002 to $0.121 \mathrm{ppb} . \mathrm{O}_{3}, \mathrm{NO}$, $\mathrm{NO}_{2}$, and $\mathrm{NO}_{x}$ concentrations were continuously monitored using i-series chemiluminescence instruments.

VOC gridded samples were collected at each site for two days (1 and 14 July 2019) and twice a day at 07:00 China standard time (CST) and 15:00 (CST). The gridded sampling site was chosen based on the technical regulations for selecting ambient air quality monitoring stations (HJ 6642013) and method for selection of Photochemical Assessment Monitoring Stations (EPA). According to the prevailing wind direction and to ensure coverage of all urban areas in Xi' an, 20 gridded sampling sites were selected for this study (Fig. 1). Detailed sampling site information is shown in Table 1. A total of 80 ambient air samples with a frequency of 4 samples per site were collected, and each sample was stored in a $3.2 \mathrm{~L}$ Silonite $^{\mathrm{TM}}$ canister (Entech Instrument, United States). Before VOC gridded sampling, the Silonite ${ }^{\text {TM }}$ canisters were cleaned with high-purity nitrogen using the Entech 3100 canister cleaning system, and then they were evacuated to a vacuum. The instantaneous sampling method was adopted for ambient air sample collection with a sampling duration of approximately $2 \mathrm{~min}$. VOCs in the sampled air were analyzed using a GC-MS/FID system, which was the same as that used for online measurements, but it was running in offline mode. In this study, blank sample tests were performed on the VOC gridded sampling in each sampling period (1 July 07:00, 1 July 15:00, 14 July 07:00, and 14 July 15:00). The concentration of all VOC species in the blank sample is below the MDLs, indicating that the canisters were not contaminated during transportation.

\subsection{Photochemical reactive activity parameterization}

The loss rates of VOCs that react with $\mathrm{OH}$ radicals $\left(\mathrm{L}_{\mathrm{OH}}\right)$ and the $\mathrm{O}_{3}$ formation potential (OFP) can be used to characterize VOC photochemical activity (Carter, 2010; Niu et al., 2016; Wu et al., 2016a). L $\mathrm{OH}_{\mathrm{OH}}$ aFP can be calculated using Eqs. (1) and (2), respectively.

$$
\begin{aligned}
& L_{\mathrm{OH}}=\sum_{i}^{n} k_{\mathrm{OH}_{i}} \times\left[\operatorname{VOC}\left(\text { molec. } \mathrm{cm}^{-3}\right)\right]_{i}, \\
& \mathrm{OFP}=\sum_{i}^{n} \mathrm{MIR}_{i} \times[\operatorname{VOC}(\mathrm{ppb})]_{i},
\end{aligned}
$$

where $n$ represents the number of VOCs, $[\mathrm{VOC}]_{i}$ represents the $i$ th $\mathrm{VOC}$ species concentration, $k_{\mathrm{OH} i}$ represents the rate coefficient for the reaction of the $i$ th VOC species with $\mathrm{OH}$ radical (molec. ${ }^{-1} \mathrm{~cm}^{3} \mathrm{~s}^{-1}$ ), and $\mathrm{MIR}_{i}$ is the maximum incremental reactivity for the $i$ th VOC species. The $k_{\mathrm{OH} i}$ and MIR for each VOC species were taken from the updated Carter research results (http://www.engr.ucr.edu/ carter/reactdat.htm, last access: 24 February 2021).

Specific VOC ratios are often used to calculate the air mass photochemical age or $\mathrm{OH}$ exposure (Jimenez et al., 2009; Roberts et al., 1984). OH exposure can be calculated using
Eq. (3).

$$
\mathrm{OH} \text { exposure }=\frac{1}{\left(k_{\mathrm{voc} 1}-k_{\mathrm{voc} 2}\right)} \times\left[\left.\ln \frac{[\operatorname{voc} 1]}{[\operatorname{voc} 2]}\right|_{t=0}-\ln \frac{[\operatorname{voc} 1]}{[\operatorname{voc} 2]}\right],
$$

where $\mathrm{OH}$ exposure represents $\mathrm{OH}$ radical concentration multiplied by the reaction time $(\Delta t) ; k_{\mathrm{voc} 1}$ and $k_{\mathrm{voc} 2}$ represent rate coefficients for the reaction of the VOC species with $\mathrm{OH}$ radical (molec. ${ }^{-1} \mathrm{~cm}^{3} \mathrm{~s}^{-1}$ ); $\left.\frac{\text { [VOC1] }}{[\text { VOC2 }}\right|_{t=0}$ represents the initial emission ratio of specific VOCs, which can be replaced by the highest concentration ratio in periods where the photochemical reaction is weak; and $[$ VOC1] [VOC2] concentration ratio of the specific VOCs in the atmosphere.

\subsection{Positive matrix factorization (PMF)}

The PMF analysis model was first proposed by Paatero and Tapper (1994). For more than two decades, PMF has been widely used to identify and quantify major sources of VOCs (He et al., 2019; Li et al., 2015; Miller et al., 2002; Pallavi et al., 2019; Song et al., 2007; Yuan et al., 2010). The definition and usage of the PMF model is described elsewhere in detail (Liu et al., 2020; Song et al., 2018; Su et al., 2019), and only a brief description is provided here.

In this study, the PMF 5.0 model (EPA) was used to analyze the VOC sources at the CB, DHS, and QL sites. VOCs tracers were selected according to the reported typical emission source profiles in China (He et al., 2015; Liu et al., 2008a; Song et al., 2018). Only those tracers which have data coverage greater than $75 \%$ during the campaign and have $65 \%$ measured concentrations above the MDL were included in the PMF analysis (cf. Liu et al., 2020). In this study, the number of VOC tracers (input species) at the CB, DHS, and QL sites were 32, 34, and 32, respectively. A concentration (Conc.) file and uncertainty (Unc) file are required by PMF. For the concentration file, data below the detection limit were assigned with MDL/2, and the missing data were substituted with median concentration. The uncertainty is calculated using Eq. (4) as follows (Brown et al, 2015; Liu et al, 2016a):

Unc $=\left\{\begin{array}{ll}\sqrt{(\text { Error Fraction } \times \text { Conc. })^{2}+(0.5 \times \text { MDL })^{2}} & \text { Conc. }>\text { MDL } \\ 5 & \text { Conc. } \leq \text { MDL } \\ 4 \times \text { Conc. } & \text { Missing data }\end{array}\right.$.

In this study, the PMF factor numbers were explored from 4 to 8 for the optimal solution in the three sites. $Q_{\text {true }} / Q_{\text {robust }}$ and $Q_{\text {true }} / Q_{\text {expected }}$ are two important parameters for characterizing the rationality of the PMF results (Brown et al., 2015). After comparing the PMF results, $Q_{\text {true }} / Q_{\text {robust }}$ ratio, and $Q_{\text {true }} / Q_{\text {expected }}$ ratio, a seven-factor PMF solution was selected for VOC source apportionments in the three field observation sites. The $Q_{\text {true }} / Q_{\text {robust }}$ values at the CB, DHS, and QL sites were all 1.0. The $Q_{\text {true }} / Q_{\text {expected values at the }}$ $\mathrm{CB}$, DHS, and QL sites were 1.3, 1.2, and 1.0, respectively. In addition, an Fpeak parameter, from -1.0 to 1.0 (step of 0.1 ), was used to rotate the PMF factors for a superior solution (Sun et al., 2012). In this study, the factor rotating results 


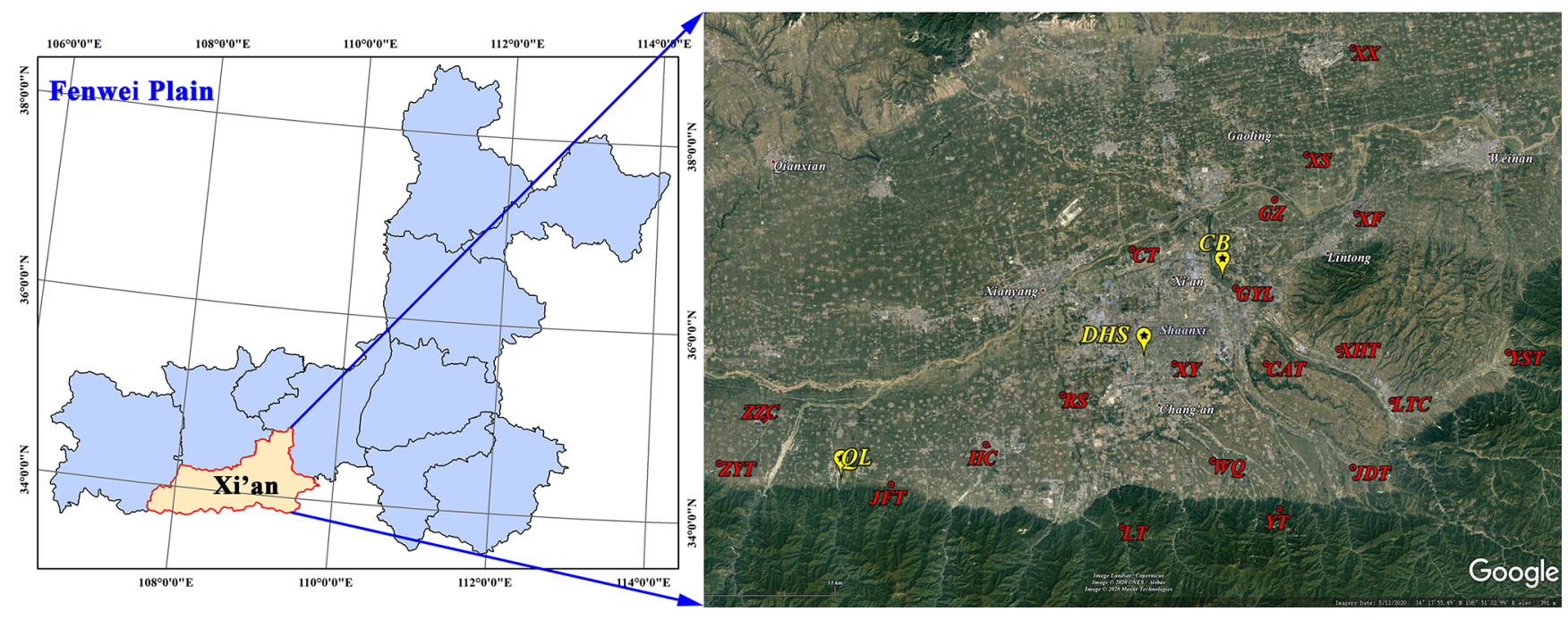

Figure 1. VOC field observation and grid sampling sites in Xi' an (@ Google Earth). The topographic image was obtained from Google Earth.

Table 1. Detailed sampling site information.

\begin{tabular}{|c|c|c|c|c|}
\hline Site name & Abbreviation & Latitude & Longitude & Parameter \\
\hline Chanba & $\mathrm{CB}$ & $34^{\circ} 20^{\prime} 12^{\prime \prime} \mathrm{N}$ & $109^{\circ} 01^{\prime} 35^{\prime \prime} \mathrm{E}$ & $\mathrm{O}_{3} / \mathrm{NO} / \mathrm{NO}_{2} / \mathrm{NO}_{x} / \mathrm{CO} /$ photolysis rate/ \\
\hline Di Huan Suo & DHS & $34^{\circ} 13^{\prime} 49^{\prime \prime} \mathrm{N}$ & $108^{\circ} 52^{\prime} 58^{\prime \prime} \mathrm{E}$ & VOCs $(99) / T / P / R H$ \\
\hline Qinling & QL & $34^{\circ} 04^{\prime} 11^{\prime \prime} \mathrm{N}$ & $108^{\circ} 20^{\prime} 31^{\prime \prime} \mathrm{E}$ & \\
\hline Caotan & $\mathrm{CT}$ & $34^{\circ} 23^{\prime} 4^{\prime \prime} \mathrm{N}$ & $108^{\circ} 52^{\prime} 13^{\prime \prime} \mathrm{E}$ & VOCs (106) \\
\hline College of Automotive Technology & CAT & $34^{\circ} 12^{\prime} 48^{\prime \prime} \mathrm{N}$ & $109^{\circ} 5^{\prime} 54^{\prime \prime} \mathrm{E}$ & \\
\hline Gengzhen Subdistrict Office & GZ & $34^{\circ} 26^{\prime} 52^{\prime \prime} \mathrm{N}$ & $109^{\circ} 7^{\prime} 31^{\prime \prime} \mathrm{E}$ & \\
\hline Guang Yun Lake & GYL & $34^{\circ} 19^{\prime} 23^{\prime \prime} \mathrm{N}$ & $109^{\circ} 3^{\prime} 1^{\prime \prime} \mathrm{E}$ & \\
\hline $\mathrm{Hu}$ County & $\mathrm{HC}$ & $34^{\circ} 6^{\prime} 43^{\prime \prime} \mathrm{N}$ & $108^{\circ} 0^{\prime} 36^{\prime \prime} \mathrm{E}$ & \\
\hline Jiaodai Town & JDT & $34^{\circ} 3^{\prime} 33^{\prime \prime} \mathrm{N}$ & $109^{\circ} 14^{\prime} 39^{\prime \prime} \mathrm{E}$ & \\
\hline Jiufen Town & JFT & $34^{\circ} 3^{\prime} 35^{\prime \prime} \mathrm{N}$ & $108^{\circ} 25^{\prime} 50^{\prime \prime} \mathrm{E}$ & \\
\hline Lantian County & LTC & $34^{\circ} 9^{\prime} 9^{\prime \prime} \mathrm{N}$ & $109^{\circ} 19^{\prime} 5^{\prime \prime} \mathrm{E}$ & \\
\hline Luan Town & LT & $33^{\circ} 59^{\prime} 14^{\prime \prime} \mathrm{N}$ & $108^{\circ} 50^{\prime} 4^{\prime \prime} \mathrm{E}$ & \\
\hline Region Site & RS & $34^{\circ} 10^{\prime} 45^{\prime \prime} \mathrm{N}$ & $108^{\circ} 44^{\prime} 18^{\prime \prime} \mathrm{E}$ & \\
\hline Wangqu Subdistrict Office & WQ & $34^{\circ} 4^{\prime} 36^{\prime \prime} \mathrm{N}$ & $108^{\circ} 59^{\prime} 54^{\prime \prime} \mathrm{E}$ & \\
\hline Xiaoyan & $\mathrm{XY}$ & $34^{\circ} 13^{\prime} 4^{\prime \prime} \mathrm{N}$ & $108^{\circ} 56^{\prime} 15^{\prime \prime} \mathrm{E}$ & \\
\hline Xiehu Town & XHT & $34^{\circ} 13^{\prime} 47^{\prime \prime} \mathrm{N}$ & $109^{\circ} 13^{\prime} 41^{\prime \prime} \mathrm{E}$ & \\
\hline Xinfeng Subdistrict Office & $\mathrm{XF}$ & $34^{\circ} 25^{\prime} 23^{\prime \prime} \mathrm{N}$ & $109^{\circ} 16^{\prime} 12^{\prime \prime} \mathrm{E}$ & \\
\hline Xinshi Subdistrict Office & XS & $34^{\circ} 30^{\prime} 38^{\prime \prime} \mathrm{N}$ & $109^{\circ} 11^{\prime} 7^{\prime \prime} \mathrm{E}$ & \\
\hline Xinxing Subdistrict Office & $\mathrm{XX}$ & $34^{\circ} 39^{\prime} 43^{\prime \prime} \mathrm{N}$ & $109^{\circ} 16^{\prime} 29^{\prime \prime} \mathrm{E}$ & \\
\hline Yin Town & $\mathrm{YT}$ & $34^{\circ} 0^{\prime} 17^{\prime \prime} \mathrm{N}$ & $109^{\circ} 6^{\prime} 44^{\prime \prime} \mathrm{E}$ & \\
\hline Yushan Town & YST & $34^{\circ} 12^{\prime} 53^{\prime \prime} \mathrm{N}$ & $109^{\circ} 31^{\prime} 33^{\prime \prime} \mathrm{E}$ & \\
\hline Zhouzhi County & $\mathrm{ZZC}$ & $34^{\circ} 9^{\prime} 35^{\prime \prime} \mathrm{N}$ & $108^{\circ} 12^{\prime} 33^{\prime \prime} \mathrm{E}$ & \\
\hline Zhuyu Town & ZYT & $34^{\circ} 5^{\prime} 50^{\prime \prime} \mathrm{N}$ & $108^{\circ} 7^{\prime} 41^{\prime \prime} \mathrm{E}$ & \\
\hline
\end{tabular}

$T$ : temperature; $P$ : pressure; RH: humidity. 
were not significantly different than the non-rotation results. Thus, the results used in this study were from the runs with zero Fpeak.

\subsection{Conditional probability function (CPF) analyses}

A CPF analysis can be used to explore the PMF-identified VOC source impacts at varying wind directions and speeds (Huang and Hsieh, 2019; Liu et al., 2016a). The CPF can be calculated using Eq. (5) as follows (Ashbaugh et al., 1985; Uria-Tellaetxe and Carslaw, 2014):

$\mathrm{CPF}=\frac{m_{\theta, \mu, 75 \text { per }}}{n_{\theta, \mu}}$,

where $m_{\theta, \mu, 75 \text { per }}$ is the number of samples in the wind direction $\theta$ and wind speed interval $\mu$ with a VOC concentration greater than the 75th percentile concentration, and $n_{\theta, \mu}$ is the total number of samples in the same wind direction and speed interval.

\subsection{Cluster and potential source contribution function (PSCF) analysis}

Cluster analyses of backward trajectories are widely used to determine a dominant air mass direction and potential origin direction of pollutants at the study sites (Hong et al., 2019; Liu et al., 2016a, 2019). In this study, the $24 \mathrm{~h}$ backward trajectories ( $1 \mathrm{~h}$ intervals) of air masses arriving $100 \mathrm{~m}$ above ground level were calculated using the MeteoInfoMap software. Air mass reanalysis data were obtained from the National Weather Service's National Centers for Environmental Prediction at a gridded resolution of $0.25^{\circ} \times 0.25^{\circ}$ (ftp://arlftp.arlhq.noaa.gov/pub/ archives/gfs0p25, last access: 24 February 2021). The Euclidean distance clustering algorithm was chosen to cluster the air mass trajectories in the CB, DHS, and QL sites from 20 June to 20 July 2019 . To obtain the optimal clustering solution, the clustering result with the smallest percent change was selected (Wang et al., 2010).

PSCF is a gridded statistical analysis method that is used to combine the backward trajectory and the corresponding VOC concentration to determine the potential VOC source area (Liu et al., 2016b, 2020; Zheng et al., 2018). In this study, $\mathrm{Xi}$ ' an city and the adjacent region covered by the back trajectories were divided into an array of $0.25^{\circ} \times 0.25^{\circ}$ grid cells. In this study, the pollution trajectory was defined as the trajectories corresponding to the total VOC (TVOC) concentration that exceeded the 75th percentile concentration of TVOCs. When the number of endpoints of the pollution trajectory passing through the grid $(i, j)$ is $M_{i j}$, and the number of endpoints of all the trajectories falling within the grid $(i$, $j$ ) is $N_{i j}$, then $\mathrm{PSCF}_{i j}$ can be defined as the ratio of $M_{i j}$ to $N_{i j}$ (Polissar et al., 1999). The weight function $W_{i j}$ was used to increase the accuracy of the model, and $\mathrm{PSCF}_{i j}$ can be calculated using Eq. (6) as follows:

$\operatorname{PSCF}_{i j}=\frac{M_{i j}}{N_{i j}} \times W_{i j}=\frac{M_{i j}}{N_{i j}} \times\left\{\begin{array}{ll}1.00 & N_{i j}>80 \\ 0.70 & 40<N_{i j} \leq 80 \\ 0.42 & 5<N_{i j} \leq 40 \\ 0.05 & N_{i j} \leq 5\end{array}\right.$.

\subsection{Empirical kinetic modeling approach}

The traditional empirical kinetic modeling approach (EKMA) is a model sensitivity test of the observation-based box model and often used to evaluate the photochemical nonlinear relationship between ozone and precursors $\mathrm{NO}_{x}$ and VOCs. The box model is based on the Regional Atmospheric Chemical Mechanisms version 2 (Goliff et al., 2013) updated with the Leuven Isoprene Mechanism (Peeters et al., 2009). The definition and mechanism of the observation-based box model is described elsewhere in detail (Tan et al., 2017, 2018).

The EKMA curve can be used as a theoretical basis for designing emission reduction strategies to obtain the best ozone pollution reduction method (Jiang et al. 2018; Tan et al., 2018). The model input parameters include temperature, pressure, humidity, photolysis rate constant, $\mathrm{NO}_{2}$, and VOCs. In this model, the ozone production rate $\mathrm{P}\left(\mathrm{O}_{3}\right)$ is calculated by the ozone formation rate $F\left(\mathrm{O}_{3}\right)$ minus the ozone loss rate $D\left(\mathrm{O}_{3}\right)$, as shown in Eq. (7). The ozone formation rate $F$ $\left(\mathrm{O}_{3}\right)$ and the ozone loss rate $D\left(\mathrm{O}_{3}\right)$ can be calculated using Eqs. (8) and (9) as follows:

$$
\begin{aligned}
P_{\mathrm{O}_{3}} & =F_{\mathrm{O}_{3}}-D_{\mathrm{O}_{3}}, \\
F_{\mathrm{O}_{3}} & =k_{\mathrm{HO}_{2}+\mathrm{NO}}\left[\mathrm{HO}_{2}\right][\mathrm{NO}]+k_{\left(\mathrm{RO}_{2}+\mathrm{NO}\right)_{\text {eff }}}\left[\mathrm{RO}_{2}\right][\mathrm{NO}], \\
D_{\mathrm{O}_{3}} & =\left[\mathrm{O}^{1} \mathrm{D}\right]\left[\mathrm{H}_{2} \mathrm{O}\right]+k_{\mathrm{O}_{3}+\mathrm{OH}}\left[\mathrm{O}_{3}\right][\mathrm{OH}]+k_{\mathrm{O}_{3}+\mathrm{HO}_{2}} \\
& {\left[\mathrm{O}_{3}\right]\left[\mathrm{HO}_{2}\right]+k_{\mathrm{O}_{3}+\text { alkenes }}\left[\mathrm{O}_{3}\right][\text { alkenes}]+k_{\mathrm{OH}+\mathrm{NO}_{2}} } \\
& {[\mathrm{OH}]\left[\mathrm{NO}_{2}\right], }
\end{aligned}
$$

where $k_{\mathrm{HO}_{2}+\mathrm{NO}}$ represents rate coefficients for the reaction of the $\mathrm{NO}$ with $\mathrm{HO}_{2}$ radical $\left(8.5 \times 10^{-12}\right.$ molec. ${ }^{-1} \mathrm{~cm}^{3} \mathrm{~s}^{-1}$, $298 \mathrm{~K}), \quad k_{\left(\mathrm{RO}_{2}+\mathrm{NO}\right)_{\text {eff }}}$ represents effective rate coefficients for the reaction of the NO with $\mathrm{RO}_{2}$ radical $\left(8.5 \times 10^{-12}\right.$ molec $\left.^{-1} \mathrm{~cm}^{3} \mathrm{~s}^{-1}, 298 \mathrm{~K}\right), \mathrm{k}_{\mathrm{O}_{3}+\mathrm{OH}}$ represents rate coefficients for the reaction of the $\mathrm{O}_{3}$ with $\mathrm{OH}$ radical $\left(7.3 \times 10^{-14}\right.$ molec. $\left.{ }^{-1} \mathrm{~cm}^{3} \mathrm{~s}^{-1}, 298 \mathrm{~K}\right), k_{\mathrm{O}_{3}+\mathrm{HO}_{2}}$ represents rate coefficients for the reaction of the $\mathrm{O}_{3}$ with $\mathrm{HO}_{2}$ radical $\left(1.9 \times 10^{-15}\right.$ molec. $\left.{ }^{-1} \mathrm{~cm}^{3} \mathrm{~s}^{-1}, 298 \mathrm{~K}\right), k_{\mathrm{O}_{3}+\text { alkenes }}$ represents rate coefficients for the reaction of the $\mathrm{O}_{3}$ with alkenes $\left(2.0 \times 10^{-17}\right.$ molec. $\left.{ }^{-1} \mathrm{~cm}^{3} \mathrm{~s}^{-1}, 298 \mathrm{~K}\right)$, and $k_{\mathrm{OH}+\mathrm{NO}_{2}}$ represents rate coefficients for the reaction of the $\mathrm{NO}_{2}$ with $\mathrm{OH}$ radical $\left(1.1 \times 10^{-11}\right.$ molec. $\left.^{-1} \mathrm{~cm}^{3} \mathrm{~s}^{-1}, 298 \mathrm{~K}\right)$.

In this study, the average parameters of the entire observation period were used as the input parameters of the model to calculate the ozone concentration in the baseline scenario. Afterwards, the activity change array of VOCs and $\mathrm{NO}_{x}$ were generated by changing each parameter in equal distance 
steps. The $P\left(\mathrm{O}_{3}\right)$ contours under these different VOCs and $\mathrm{NO}_{x}$ reactivity conditions are called EKMA curves.

\section{Results and discussion}

\subsection{Temporal and spatial characteristics of VOCs}

\subsubsection{Temporal variations}

Temporal variations in wind speed, wind direction, temperature, relative humidity, $\mathrm{O}_{3}$, and VOCs at the $\mathrm{CB}$, DHS, and QL sites are shown in Fig. 2. During the field observation campaign, 99 VOCs were measured, including 29 alkanes, 11 alkenes, 1 alkyne, 16 aromatics, 28 halohydrocarbons, 13 oxygenated VOCs (OVOCs), and 1 acetonitrile (Supplement Table S1). The CB and DHS sites were located in an urban area of Xi' an, while the QL site was located in a rural area. During the observation period, the average VOC concentrations at the CB, DHS, and QL sites were $27.8 \pm 8.9$, $33.8 \pm 10.5$, and $15.5 \pm 5.8 \mathrm{ppb}$, respectively. Due to the existence of more emission sources and lower wind speeds ( 0 $2 \mathrm{~m} / \mathrm{s}$ ) in urban areas, the VOC concentrations were higher than those in rural areas. Overall, the VOC concentrations in Xi'an urban sites were approximately twice that of the rural sites. The observation period occurred during summer in $\mathrm{Xi}^{\prime}$ 'an, and the temperature was high, with average temperatures reaching $26.2 \pm 4.3$ and $25.6 \pm 3.9{ }^{\circ} \mathrm{C}$ in urban and rural areas, respectively. Higher temperatures may accelerate a secondary transformation of VOCs into $\mathrm{O}_{3}$, resulting in more frequent $\mathrm{O}_{3}$ pollution incidents in Xi' an; the mean $\mathrm{O}_{3}$ concentrations at the $\mathrm{CB}$, DHS, and QL sites reached $50.2 \pm 29.9,47.6 \pm 29.4$, and $19.7 \pm 8.0 \mathrm{ppb}$, respectively.

During the observation period, there were two $\mathrm{O}_{3}$ pollution events in the Xi' an urban area (CB and DHS sites), from 23 to 26 June 2019 and from 30 June to 15 July 2019. The wind speed diurnal pattern in the urban area displayed a single wave profile on both clean and polluted days with low wind speeds $(0.4 \pm 0.2$ and $0.3 \pm 0.1 \mathrm{~m} / \mathrm{s}$, respectively) during the night and peaks $(0.7 \pm 0.2$ and $0.9 \pm 0.3 \mathrm{~m} / \mathrm{s}$, respectively) at 14:00 CST. The overall wind speed in the Xi'an urban area was in a static state, indicating that the ability of wind to diffuse and dilute pollutants is limited (Fig. 3). The variation trends of $\mathrm{O}_{3}$ and temperature display a positive correlation, and the linear correlations between $\mathrm{O}_{3}$ and temperature on polluted days $\left(R_{\text {Pearson }}=0.7\right)$ is stronger than that on clean days $\left(R_{\text {Pearson }}=0.5\right)$. The value of temperature, $\mathrm{O}_{3}$, and TVOCs all increased significantly on polluted days, indicating that the secondary transformation of VOCs to $\mathrm{O}_{3}$ is more conducive at high temperatures. The difference between the VOC species concentration on clean and polluted days at the CB and DHS sites is shown in Fig. 3c and e. As shown in Fig. 3, isoprene concentrations at urban sites increased significantly during the $\mathrm{O}_{3}$ pollution day, which could be due to the stronger plant emission at elevated temperature (Guenther et al., 1993, 2012; Stavrakou et al., 2014). Concentrations of isoprene oxidation products (i.e., MVK and MACR) as well as most OVOCs also increased in the same period. However, similar concentrations of anthropogenic VOCs are found in clean and polluted days. This indicates a stronger photochemical conversion of VOCs existed in $\mathrm{O}_{3}$ pollution days, which could due to the more favorable meteorological conditions (i.e., higher temperature and solar radiation). The specialty of OVOCs is that in addition to the primary emissions, OVOCs can also be formed through photochemical oxidation with alkenes and aromatics (Birdsall and Elrod, 2011). The sources of OVOCs can be divided into anthropogenic primary sources, anthropogenic secondary sources, biogenic sources, and background sources (Li et al., 2014; Wang et al., 2015). Based on the multi-linear regression model results (Figs. S1 and S2) we found that the contribution of anthropogenic primary sources to OVOCs on $\mathrm{O}_{3}$ pollution days is more significant.

\subsubsection{Spatial variations}

In this study, the VOC grid sampling was used to investigate the spatial variations in VOCs in Xi'an. A total of 20 sites were selected for grid monitoring that covered the entire city of Xi'an. Therefore, the results of the VOC grid sampling were used to represent the levels of the entire city. In the VOC grid sampling, 106 VOCs were measured, including 29 alkanes, 11 alkenes, 1 alkyne, 17 aromatics, 35 halohydrocarbons, 12 OVOCs, and carbon disulfide (Table S2-S3). The weather parameter on 1 and 14 July in Xi' an is shown in Table S4. The average VOC concentration at the 20 sites on 1 July and 14 July 2019 was $29.1 \pm 8.4$ ppb, and high VOC concentrations were clustered at the XF, CT, HC, ZYT, and YT sites (Fig. 4a and b). Of the sites, the XF site exhibited the highest VOC concentration of $54.0 \mathrm{ppb}$, followed by CT and $\mathrm{HC}$, with concentrations of 41.4 and $38.2 \mathrm{ppb}$, respectively. The XHT site exhibited the lowest concentration of VOCs at $18.0 \mathrm{ppb}$, followed by WQ and YST sites with concentrations of 19.6 and $19.9 \mathrm{ppb}$, respectively. Compared with the results of the field observation campaign, the VOC concentration at the $\mathrm{CB}$ site was closer to the average concentration in Xi'an, and the VOC concentration at the DHS site was significantly higher than the average concentration. In terms of the VOC composition at each site, alkanes and OVOCs were dominant, accounting for $25.7 \%-39.7 \%$ and $22.8 \%-$ $47.4 \%$ of the VOC concentration, respectively. In addition, the contribution of OVOCs at the YT site was significantly higher than that of the other sites, indicating that the YT site may be significantly affected by aging sources (Fig. 4a). The top 10 VOC species at the CB, DHS, QL, and grid sampling sites accounted for $66.1 \%, 63.4 \%, 71.1 \%$, and $67.1 \%$ of the TVOC concentration, respectively (Table 2). Of these species, ethane, acetone, and propane were the top three contributors in Xi' an, accounting for $34.0 \%-41.3 \%$ of the TVOC. 


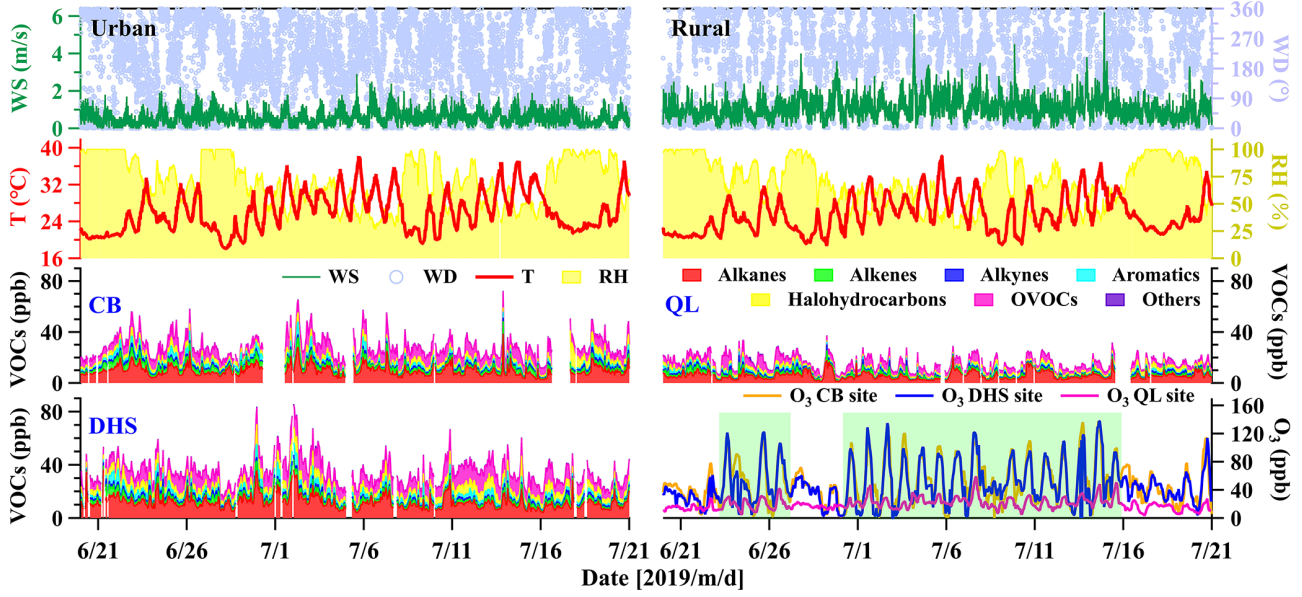

Figure 2. Time series of wind speed (WS), wind direction (WD), temperature ( $T$ ), relative humidity (RH), $\mathrm{O}_{3}$, and VOCs at the CB, DHS, and QL sites. The green area in the figure represents periods with $\mathrm{O}_{3}$ levels exceeding the Chinese national standard at the CB and DHS sites. Time is expressed in China CST.
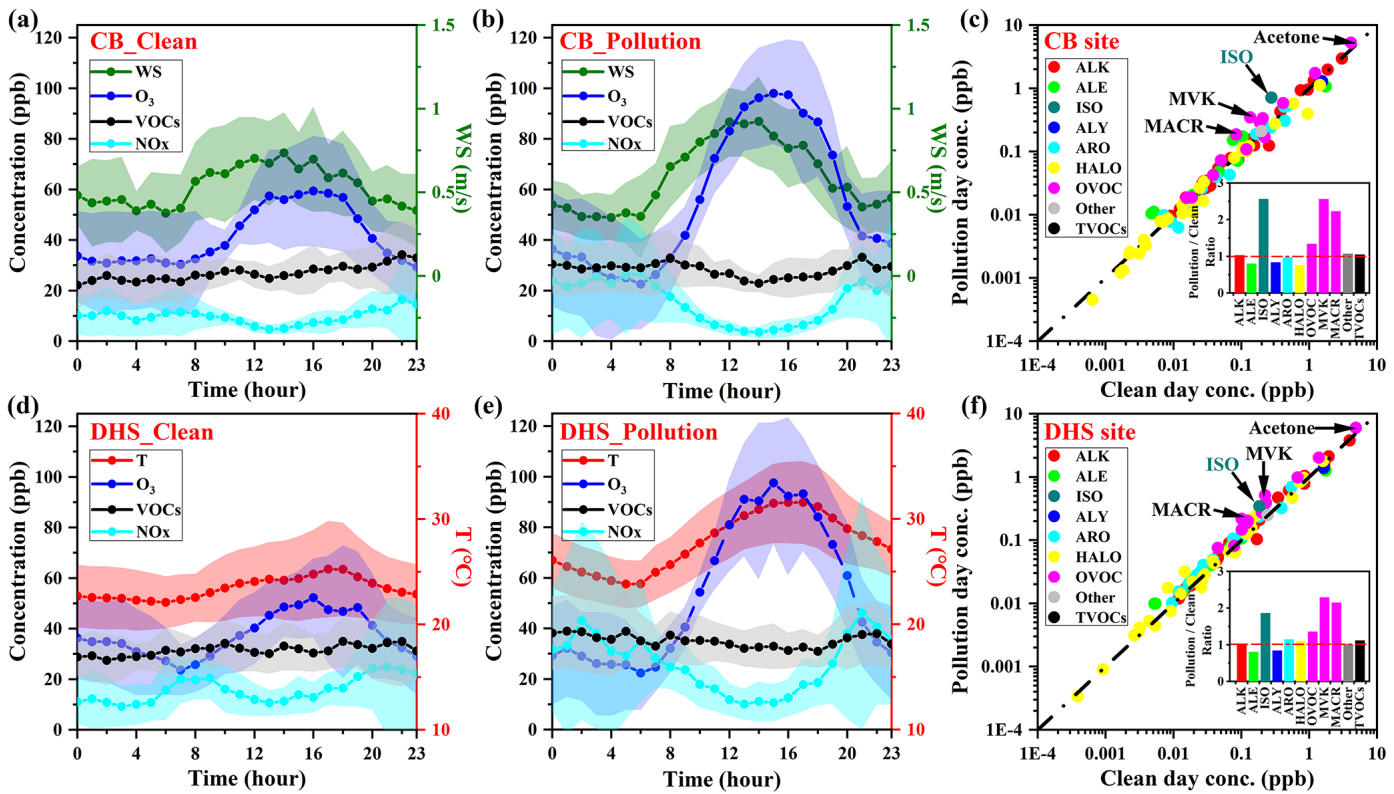

Figure 3. Diurnal variations in wind speed (WS), temperature $(T), \mathrm{O}_{3}, \mathrm{NO}_{x}$, and TVOCs on clean and polluted days at the (a, b) $\mathrm{CB}$ and (d, e) DHS sites. Differences in VOC concentrations between clean and polluted days at the (c) CB and (f) DHS sites. ALK: alkanes; ALE: alkenes (except isoprene); ISO: isoprene; ALY: alkynes; ARO: aromatics; HALO: halohydrocarbons; MVK: methyl vinyl ketone; MACR: methacrolein.

\subsection{Sources}

\subsubsection{Specific VOC ratios}

Different VOC species may have different sources; hence, the ratio of different species can be used to preliminarily analyze the difference in VOC sources at each site. The ratios of specific species that are often used are the toluene/benzene (T/B), $m / p$ xylene / ethylbenzene (X/E), iso-pentane / $n$-pentane, ben- zene / ethyne, toluene / ethyne, and $m$ / $p$-xylene / ethyne ratios.

The $\mathrm{T}$ / B ratio is clearly different for various source profiles (Table S5). In industrial source emission studies, the ratio of $\mathrm{T} / \mathrm{B}$ ranged from $1.4 \pm 0.8$ to $5.8 \pm 3.4$ by different industry type and process unit (Mo et al., 2015; Shi et al., 2015). In traffic source emission studies, the ratio of $T / B$ ranged from $0.9 \pm 0.6$ to $2.2 \pm 0.5$ by different vehicle type and fuel composition (Qiao et al., 2012; Dai et al., 2013; Wang et al., 2013; Yao et al., 2013; Zhang et al., 2013; Yao 

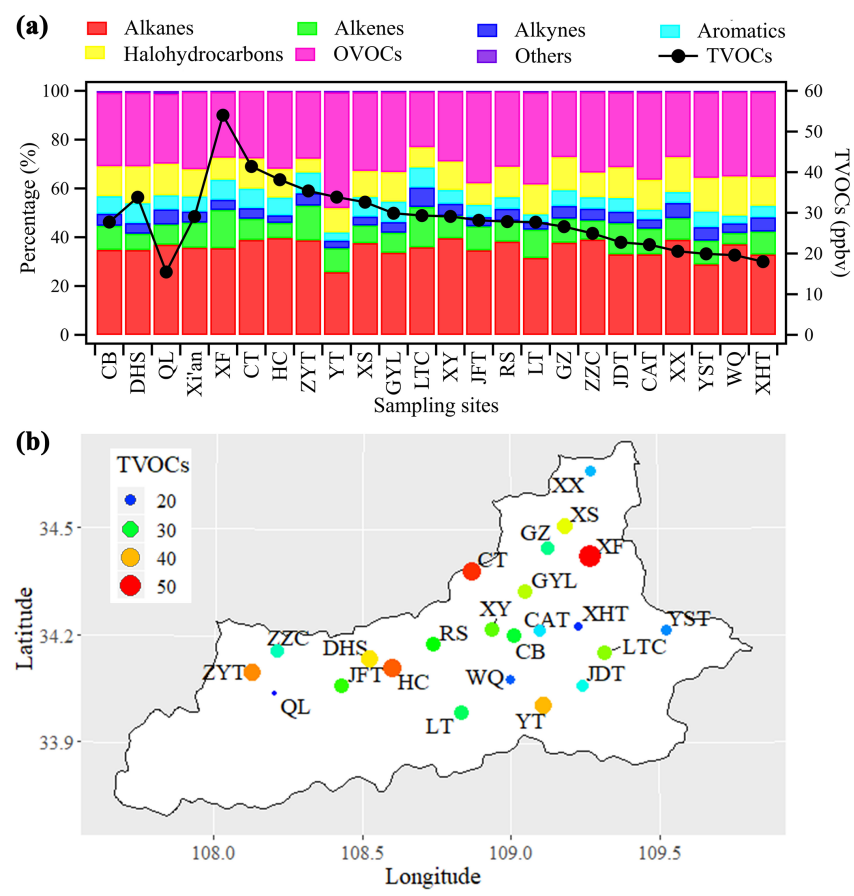

Figure 4. (a) Proportions of seven VOC groups and averaged TVOC concentrations in different sites in Xi' an. (b) Spatial distribution of averaged TVOC concentrations in different sites in Xi'an.

et al., 2015b; Mo et al., 2016; Yao et al., 2015a; Deng et al., 2018). However, vehicle emissions include both diesel vehicles emissions and gasoline vehicles emissions in the atmospheric environment. Thus, the ratio of $\mathrm{T} / \mathrm{B}$ in the traffic source should be closer to the results of the tunnel experiments which are approximately $1.5 \pm 0.1$ (Liu et al., 2008a; Deng et al., 2018). In paint solvent usage source emission studies, the ratio of $\mathrm{T} / \mathrm{B}$ was greater than $8.8 \pm 6.5$ by different solvent use process (Yuan et al., 2010; Wang et al., 2014; Zheng et al., 2013). In burning source emission studies, the $\mathrm{T} / \mathrm{B}$ ratio was approximately $0.3 \pm 0.1 \mathrm{in}$ different combustion process and raw materials (Liu et al., 2008a; $\mathrm{Li}$ et al., 2011; Mo et al., 2016). In order to reduce the influence of photochemical reaction on the ratio of benzene to toluene, this study selected the weaker photochemical reaction period (03:00-07:00) for the analysis of toluene and benzene (Fig. 5). Figure 5 shows that the ratios of toluene to benzene at the CB, DHS, QL, and gridded sampling sites were $1.1\left(R_{\text {Pearson }}=0.5\right), 3.6\left(R_{\text {Pearson }}=0.6\right), 0.5\left(R_{\text {Pearson }}=0.8\right)$, and $1.75\left(R_{\text {Pearson }}=0.9\right)$, respectively. In the urban areas (CB and DHS sites), most of the T / B ratios were distributed within the reference range of vehicle emissions and industrial emissions (Fig. 5a, b), implying that vehicle sources and industrial sources contribute significantly to the VOCs in the Xi' an urban area. In addition, the T / B value of some samples is greater than 5.8 in the urban area, which may be affected by paint solvent usage source (Fig. 5b). However, the detailed source contribution needs to be obtained through
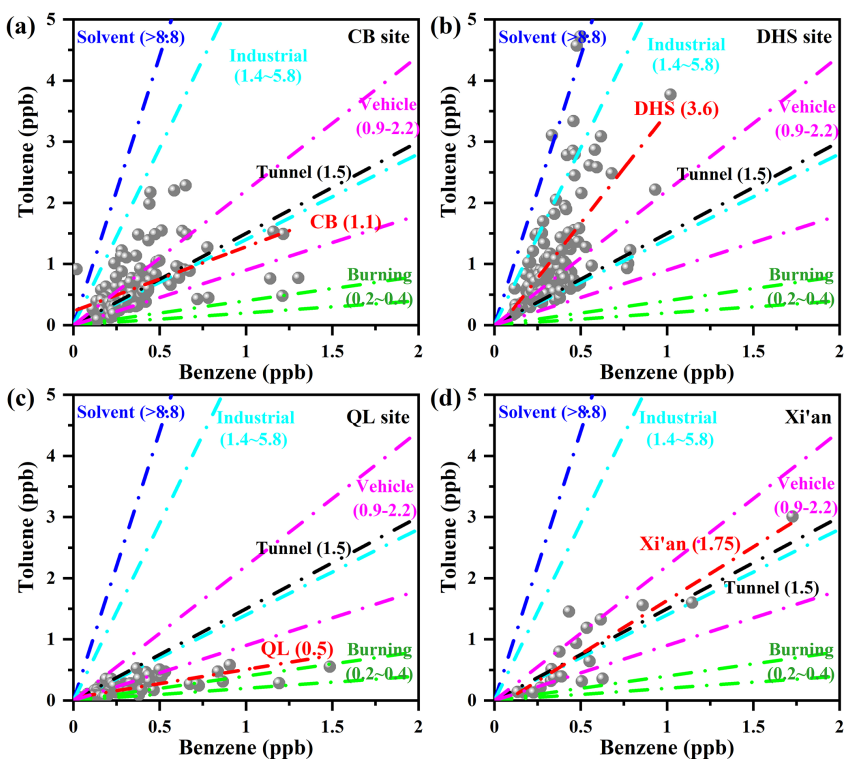

Figure 5. Linear correlations between toluene and benzene at the CB, DHS, QL, and gridded sampling sites between 03:00-07:00 during the observation period.

PMF source analysis results (Sect. 3.2.2). In the rural area (QL site), most of the $\mathrm{T} / \mathrm{B}$ ratios were distributed within the reference range of vehicle emissions and burning emissions (Fig. 5c), implying that vehicle sources and burning sources contribute significantly to the VOCs in the Xi' an rural area. In the gridded sampling sites, the $\mathrm{T} / \mathrm{B}$ ratio was predominately concentrated around 1.5 , indicating that vehicle exhaust sources may greatly contributed to the overall VOCs in Xi'an (Fig. 5d).

The reactivity of $m / p$-xylene with $\mathrm{OH}$ radicals was 2.7 times that of ethylbenzene (Carter, 2010); therefore, a lower $\mathrm{X} / \mathrm{E}$ ratio represents a higher degree of air mass aging. In areas with high air mass aging, the contribution of external source transport to VOCs increased significantly. The diurnal variation of the $\mathrm{X} / \mathrm{E}$ ratios at the $\mathrm{CB}$, DHS, and QL sites demonstrates that the $\mathrm{X} / \mathrm{E}$ ratio at the three sites significantly decreased from 09:00 to 13:00 (Fig. 6a-c). This indicated that there was a significant photochemical consumption effect on VOCs between 09:00 and 13:00. In addition, the $\mathrm{X} / \mathrm{E}$ ratios at the $\mathrm{CB}$ and DHS sites significantly increased after 13:00, while variations in the $\mathrm{X} / \mathrm{E}$ ratio were not clear at the QL site, indicating that there were more primary emissions from anthropogenic sources at the urban sites (CB and DHS sites). The diurnal variations in $\mathrm{OH}$ exposure exhibit an inverse correlation with the $\mathrm{X} / \mathrm{E}$ ratio, reaching a maximum daily value between 12:00-15:00 (Fig. 6d-f). The average $\mathrm{OH}$ exposures of the CB, DHS, and QL sites were $5.1 \times 10^{10}$, $1.7 \times 10^{10}$, and $3.1 \times 10^{10}$ molec. $\mathrm{cm}^{-3} \mathrm{~s}$, respectively.

The ratio of iso-pentane/ $n$-pentane is clearly different for various sources. Recent studies have found that the iso-pentane / $n$-pentane ratio was 2.93 for vehicle ex- 

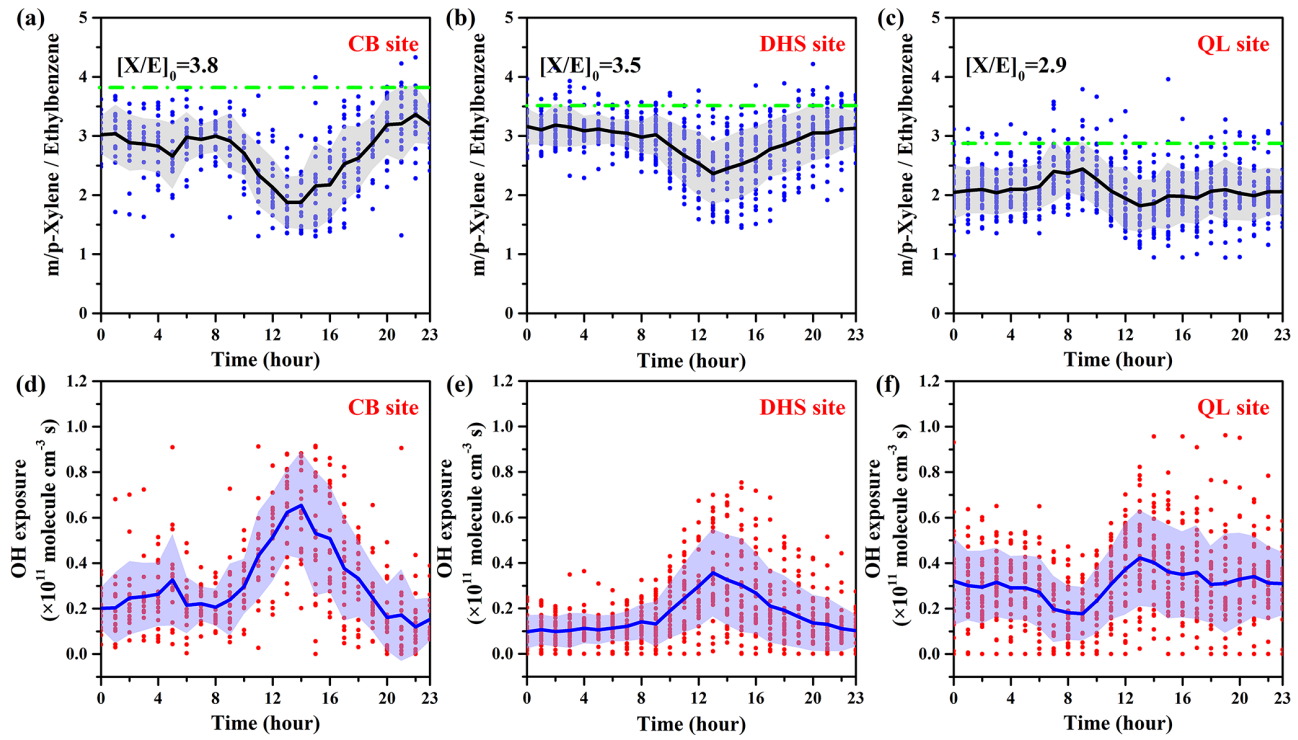

Figure 6. Diurnal variations in $m$ / p-xylene to ethylbenzene and $\mathrm{OH}$ exposure at the CB, DHS, QL, and gridded sampling sites. Time is expressed in CST. The green line represents the initial emission ratio of $m / p$-xylene and ethylbenzene.

haust sources (Liu et al., 2008a) and $0.56-0.8$ for coal burning (Yan et al., 2017). In this study, linear correlation coefficients between iso-pentane and $n$-pentane at the CB, DHS, QL, and gridded sampling sites were 1.8 $\left(R_{\text {Pearson }}=0.7\right), 1.1 \quad\left(R_{\text {Pearson }}=0.8\right), 1.5\left(R_{\text {Pearson }}=0.9\right)$, and $3.2\left(R_{\text {Pearson }}=1.0\right)$, respectively (Fig. $\left.7 \mathrm{a}\right)$. These results indicated that propane sources in Xi' an are greatly affected by vehicle emissions. Propane and ethane are the main components of liquefied petroleum gas (LPG) and natural gas (NG) (Blake and Rowland, 1995; Katzenstein et al., 2003). The propane / ethane (P / E) ratio in LPG vehicle exhaust was approximately 3 , which is significantly higher than that in gasoline and diesel vehicles (Ho et al., 2009). Therefore, the $\mathrm{P} / \mathrm{E}$ ratio is often used to indicate the impacts of LPG and NG use on VOC concentration. In this study, the linear correlation coefficients between propane and ethane at the CB, DHS, QL, and gridded sampling sites were $0.8\left(R_{\text {Pearson }}=0.8\right), 0.6\left(R_{\text {Pearson }}=0.7\right), 1.0\left(R_{\text {Pearson }}=0.9\right)$, and $0.5\left(R_{\text {Pearson }}=0.5\right)$, respectively (Fig. $\left.7 \mathrm{~b}\right)$. Xi' an buses and taxis use dual fuels (gasoline and natural gas); therefore, the $\mathrm{P} / \mathrm{E}$ ratio in $\mathrm{Xi}^{\prime}$ an is significantly lower than that in Guangzhou (1.27), where some buses and taxis use LPG fuel (Tsai et al., 2006; Wang et al., 2018; Yuan et al., 2012).

\subsubsection{Sources apportionment}

During the observation period (20 June to 20 July 2019), seven-factor PMF solutions were selected for the CB, DHS, and QL sites, and nine possible emission sources were identified: vehicle exhaust, industrial sources, combustion, paint solvent usage, biogenic sources, fuel evaporation, biogenic burning, aging sources, and vehicle exhaust + industrial sources. The source profiles and contributions to VOC con-
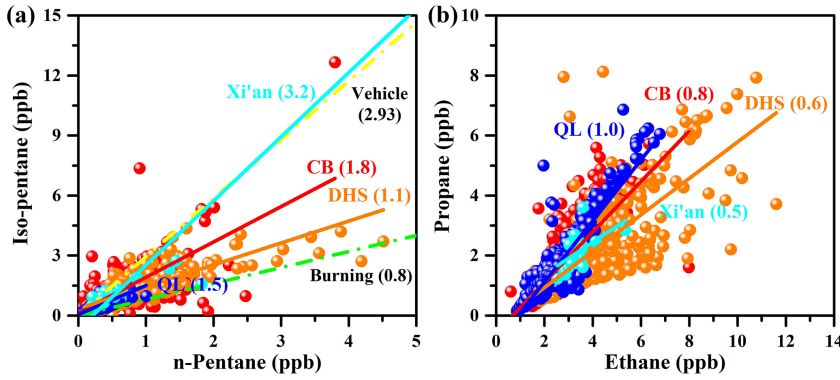

Figure 7. Linear correlations $\left(R^{2}\right)$ between (a) iso-pentane and $n$ pentane and (b) propane and ethane at the CB (red), DHS (orange), QL (blue), and gridded sampling sites (light blue).

centrations in the CB, DHS, and QL sites during the observation period are displayed in Fig. 8. The relationships between wind direction, wind speed, and the main sources of the three stations are illustrated in Fig. 9.

Vehicle exhaust sources are characterized by high concentrations of alkanes (Cai et al., 2010), a few alkenes (An et al., 2017; Liu et al., 2008a), ethyne (Ling et al., 2011), and $\mathrm{C}_{6}-\mathrm{C}_{7}$ aromatics (Mo et al., 2018). In this study, vehicle exhaust sources in the $\mathrm{CB}$ and QL sites exhibited high ethane, propane, butane, and acetone contents. In the DHS site, vehicle exhaust sources exhibited high ethane, propane, butane, pentane, ethylene, ethyne, and acetone contents and a few aromatics. These species are important vehicle exhaust tracers. Thus, these factors are identified as sources of vehicle exhaust. At the end of 2019, the number of motor vehicles in Xi' an city exceeded 3.43 million, with the city ranking eighth in China for motor vehicle number (https://www.mps.gov.cn, last access: 24 February 2021). Moreover, the contribution of 
(a) CB site

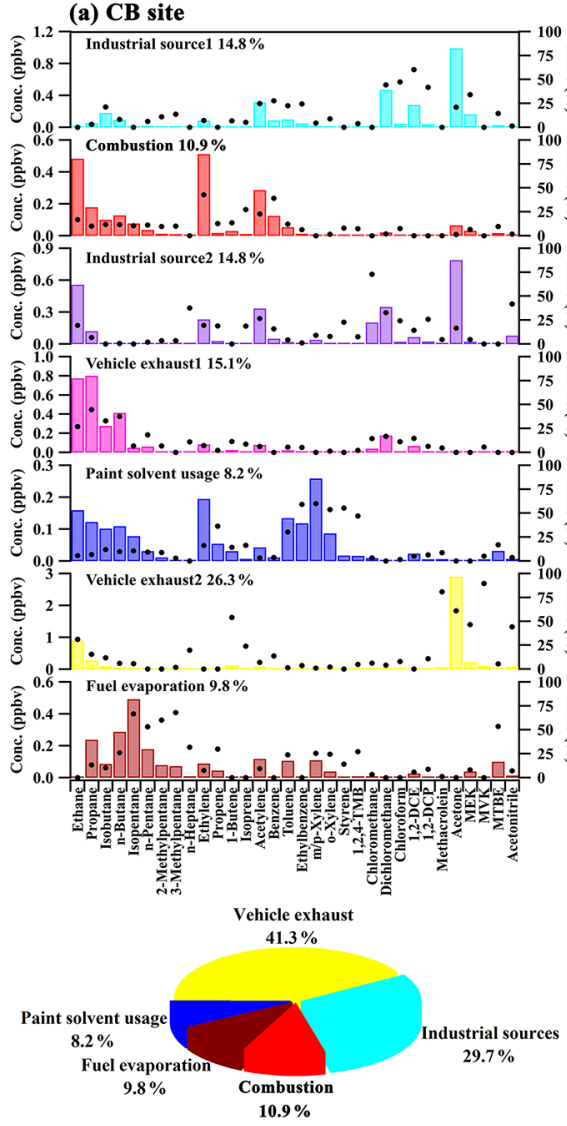

(b) DHS site

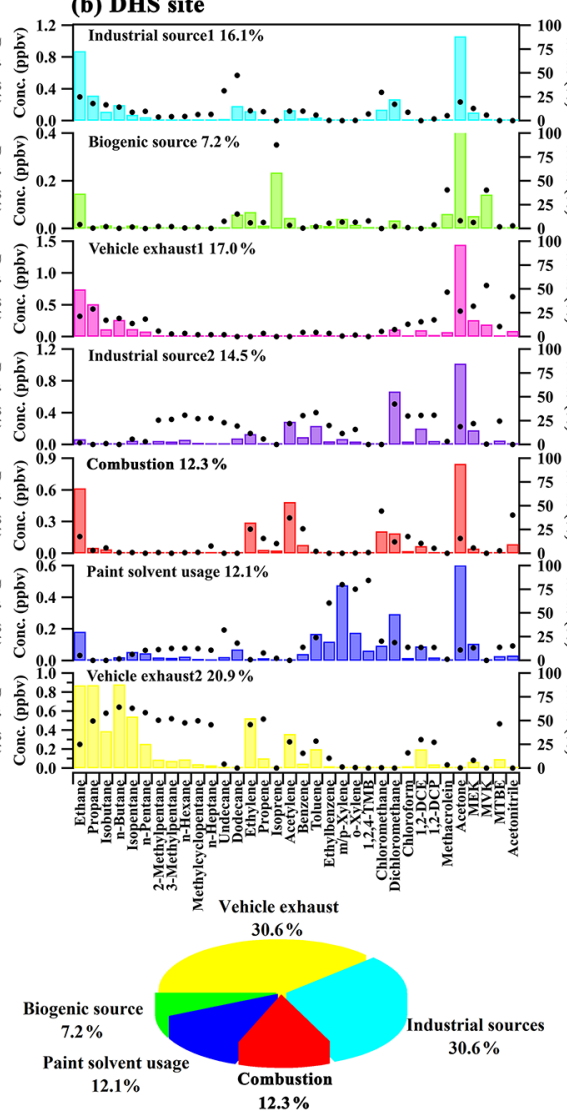

(c) QL site

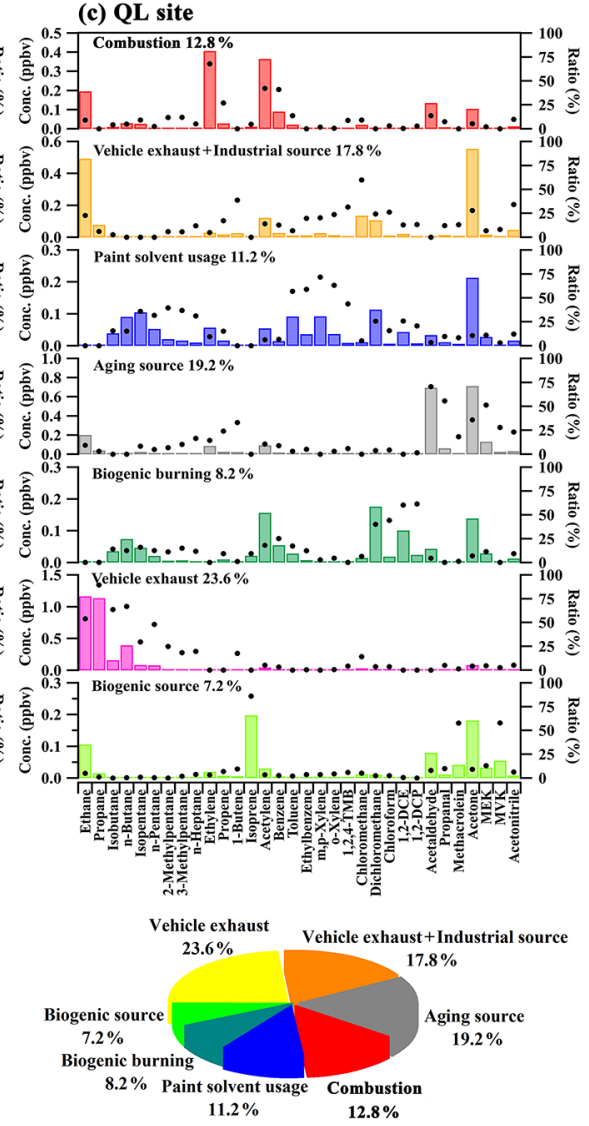

Figure 8. Source profiles and contributions of VOCs in the CB, DHS, and QL sites during the observation period. Bars represent the concentration of each species apportioned to the factor, and black dots represent the percent of each species apportioned to the factor.

vehicle exhaust to VOCs at the CB, DHS, and QL sites was $41.3 \%, 30.6 \%$, and $23.6 \%-41.4 \%$ (Fig. 8), respectively. Vehicle exhaust has become an important source of VOCs emissions in Xi' an. The CPF results in Fig. 9 indicated that vehicle exhaust at the $\mathrm{CB}$ site had a high potential $(\mathrm{CPF}>0.6)$ of source transport from the southwest when the wind speed exceeded $1 \mathrm{~m} / \mathrm{s}$. However, the vehicle exhaust at the DHS and QL sites was not significantly affected by the transmission source $(\mathrm{CPF}<0.3)$.

Industrial sources are characterized by high concentrations of halohydrocarbons (Dumanoglu et al., 2014; Sun et al., 2016) and aromatics (Guo et al., 2011). They also contain alkanes and alkenes, such as ethane, hexane, and ethylene (Liu et al., 2008a), which are important raw materials for industrial production. Factors that meet these characteristics were identified in this study as industrial sources. The industrial sources of the CB site contained a higher proportion of $n$-undecane and $n$-dodecane, which are important tracers for asphalt industry applications (Liu et al., 2008a). The source contribution results demonstrate that industrial emissions are the second-largest source of VOC emissions in the urban areas of Xi' an, accounting for $29.7 \%$ and $30.6 \%$ at the CB and DHS sites, respectively (Fig. 8). Because the QL site is located in a rural area with few factories, the contribution of industrial sources is small. The CPF results (Fig. 9) indicated that industrial sources at the CB and DHS sites were not significantly affected by the transmission source $(\mathrm{CPF}<0.3)$.

Combustion sources are characterized by high concentrations of ethane, ethylene, propane, and ethyne (Ling et al., 2011; Liu et al., 2008a; Song et al., 2018). Factors that meet these characteristics were identified as combustion sources in this study. Combustion sources have become the third-largest source of VOCs in Xi' an, accounting for $10.9 \%, 12.3 \%$, and $12.8 \%$ at the CB, DHS, and QL sites, respectively (Fig. 8). The CPF results demonstrated that combustion sources at the QL site exhibited a high potential $(\mathrm{CPF}>0.8)$ of source transport from the north when the wind speed exceeded $3 \mathrm{~m} / \mathrm{s}$ (Fig. 9).

Paint solvent usage sources are characterized by high concentrations of aromatics, such as toluene, ethylbenzene, $m / p$-xylene, and $o$-xylene (An et al., 2017; Li et al., 2018; Song et al., 2019). Factors that meet these characteristics were identified as paint solvent usage sources in this study. Paint solvent usage sources contributed significantly to the VOCs in Xi' an, accounting for $8.2 \%, 12.1 \%$, and $11.2 \%$ at 


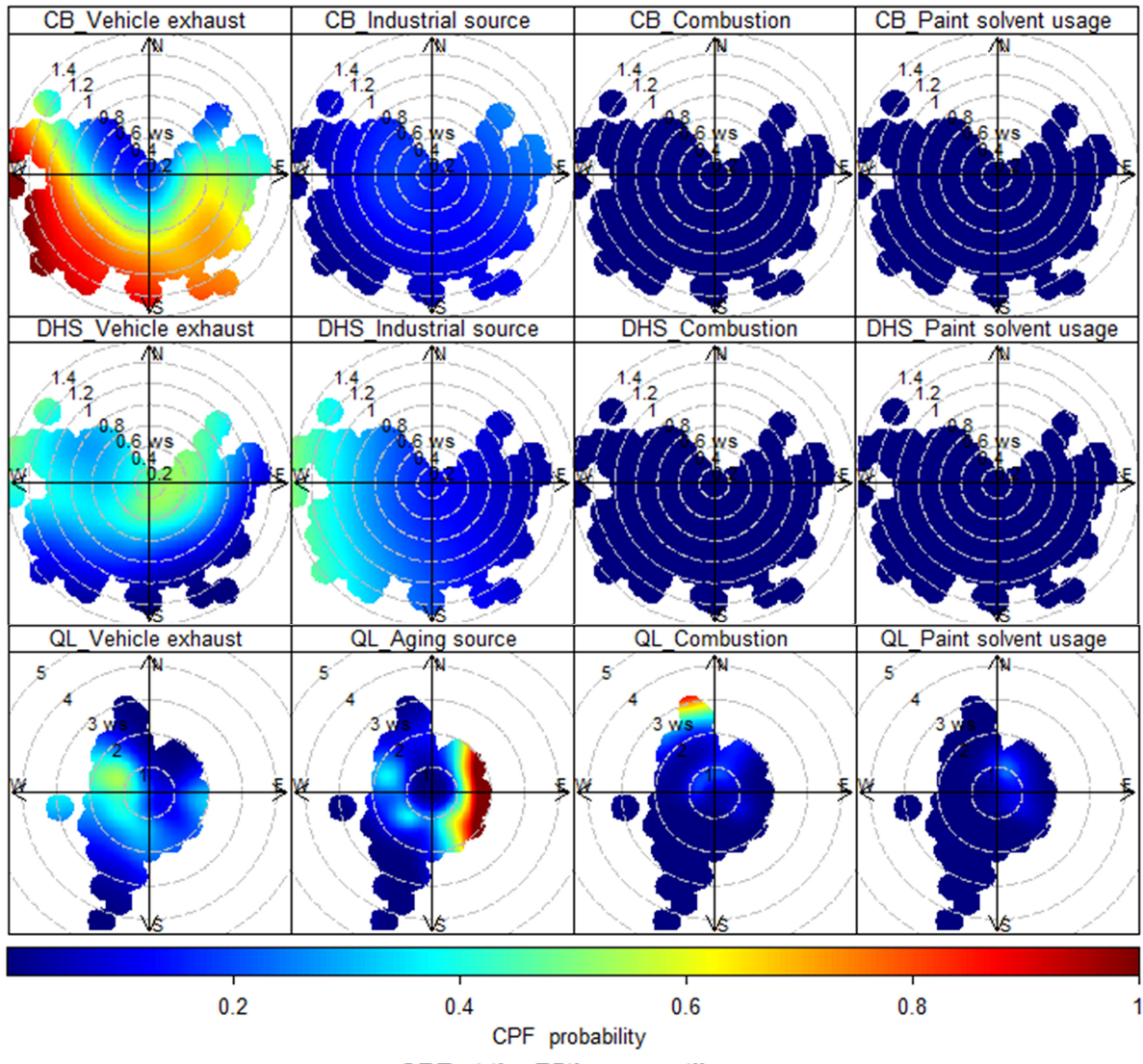

CPF at the 75th percentile

Figure 9. Polar plot of primary VOC sources in (a) CB, (b) DHS, and (c) QL sites based on the CPF function.

the CB, DHS, and QL sites, respectively (Fig. 8), which was comparable to the contribution of combustion sources.

Biogenic sources are characterized by high concentrations of isoprene and the oxidation products of isoprene (methacrolein and methyl vinyl ketone) (Gong et al., 2018; Ling and Guo, 2014; Ling et al., 2019). Factors that meet these characteristics were identified as biogenic sources in this study. Biogenic sources were identified at the DHS and CB sites, accounting for $7.2 \%$ in both sites (Fig. 8).

Biogenic burning sources are characterized by high concentrations of ethyne, methyl chloride, benzene, and toluene (Liu et al., 2008a). The fifth factor of the QL site met this characteristic and was identified as a biogenic burning source, accounting for $8.2 \%$ (Fig. 8).

Fuel evaporation sources are characterized by high concentrations of iso-butane, $n$-butane, iso-pentane, $n$-pentane, 2-methylpentane, and 3-methylpentane (Liu et al., 2017; Zheng et al., 2020). The seventh factor of the CB site met this characteristic and is identified as a fuel evaporation source, accounting for $9.8 \%$ (Fig. 8).

Aging sources are characterized by high concentrations of OVOCs (Li et al., 2015; Zhu et al., 2018). As important tracers of aging sources, OVOCs include both primary and secondary sources and have a longer lifetime in the atmo- sphere (Derstroff et al., 2017). The fourth factor of the QL site met this characteristic and was identified as an aging source, accounting for $19.2 \%$ (Fig. 8). The CPF results illustrate that aging sources at the QL site exhibited a high potential $(\mathrm{CPF}>0.8)$ of source transport from the east when the wind speed exceeded $1 \mathrm{~m} / \mathrm{s}$ (Fig. 9).

\subsection{Cluster and PSCF results}

The $24 \mathrm{~h}$ backward trajectories from Xi'an for the cluster and PSCF analysis are shown in Fig. 10. Based on the figure, air mass back trajectories can be clustered into the eastern trajectories (Cluster 1), southeastern trajectories (Cluster $2+4)$, and northeastern trajectories (Cluster $3+5$ ) at the CB site (Fig. 10a). It is evident that the proportion of southeastern trajectories to the total trajectories and that of the southeastern pollution trajectories to the total pollution trajectories were significantly higher than those of the other cluster trajectories, accounting for $58.7 \%$ and $60.8 \%$, respectively (Table 3 ). There were two trajectory clusters from the southeast direction, the southeast short distance trajectories (Cluster 2) and southeast medium-long-distance trajectories (Cluster 4), accounting for $35.2 \%$ and $23.5 \%$, respectively. This result indicated that the VOC concentration in the 
CB site was significantly affected by the southeast trajectory from the junction of the Shaanxi Province, Hubei Province, and Henan Province in addition to local sources. In addition, although the proportion pollution trajectories from the northwest (LDT) was small (Cluster 3), the concentrations in these pollution trajectories were the greatest, reaching $41.5 \mathrm{ppb}$ (Table 3). Thus, attention should be paid to the long-distance transmission of highly polluting air masses from Inner Mongolia. Regarding the VOC composition (Fig. 10b), alkanes with lower activities accounted for a larger proportion in the long-distance trajectories (Cluster 3).

The air mass back trajectories can be clustered into the eastern trajectories (Cluster 1), southeastern trajectories (Cluster 2+4), and northeastern trajectories (Cluster $3+5$ ) at the DHS site (Fig. 10c). It is evident that the proportion of southeast trajectories to the total trajectories and that of the southeast pollution trajectories to the total pollution trajectories were significantly higher than those of the other cluster trajectories, accounting for $68.9 \%$ and $73.3 \%$, respectively (Table 3). This result indicated that the VOC concentration in the DHS site was mainly affected by pollution transmission at the Shaanxi Province, Hubei Province, and Henan Province junction and local source emissions. In addition, although the proportion of pollution trajectories from the northwest (LDT) was small (Cluster 3), the concentrations in these pollution trajectories were the greatest, reaching $57.9 \mathrm{ppb}$. Thus, attention should be paid to the long-distance transmission of highly polluting air masses from central Inner Mongolia.

The air mass back trajectories can be clustered into the eastern trajectories (Cluster 1), northwestern trajectories (Cluster 2), southeastern trajectories (Cluster $3+4$ ), and northeastern trajectories (Cluster 5) at the QL site (Fig. 10e). It is evident that the proportion of northeastern trajectories to the total trajectories and that of the northeastern pollution trajectories to the total pollution trajectories were significantly higher than those of the other cluster trajectories, accounting for $36.4 \%$ and $34.3 \%$, respectively (Table 3 ). However, the VOC concentrations of the eastern trajectories to the total trajectories were significantly higher than those of the other cluster trajectories, reaching $18.7 \mathrm{ppb}$. This result indicated that the VOC concentration in the QL site was significantly affected by the eastern trajectory from the junction of the Shanxi Province, Shaanxi Province, and Henan Province in addition to local sources.

Based on the PSCF analysis for Xi' an (Fig. 10a, c, and e), in the urban sites, high PSCF values were mainly observed to the east and south of Xi' an, and in rural sites, the high PSCF values were primarily observed to the east of Xi' an. Different air mass tracking times $(6,12,24 \mathrm{~h})$ were used in the PSCF analysis of different VOC species (Fig. S3). Strong chemically active species (e.g., ethylene and xylene) had shorter air mass tracks, with high PSCF values appearing in areas near sites. However, the high PSCF values of long-lifetime species (acetone) were found not only near the site but also in the eastern and southern regions of the site. The highest PSCF values of TVOCs appeared in areas near the CB, DHS, and QL sites, which indicated that $\mathrm{Xi}$ ' an has a strong local source.

\subsection{Secondary transformation potential}

\subsection{1 $\mathrm{L}_{\mathrm{OH}}$ and $\mathrm{OFP}$}

The VOC loss rates $\left(\mathrm{L}_{\mathrm{OH}}\right)$ that react with $\mathrm{OH}$ at the $\mathrm{CB}$, DHS, and QL sites were 4.9, 4.8, and $2.4 \mathrm{~s}^{-1}$, respectively. The average $\mathrm{L}_{\mathrm{OH}}$ of the VOCs at the 20 gridded sites was $5.0 \mathrm{~s}^{-1}$, and high VOC $\mathrm{L}_{\mathrm{OH}}$ was concentrated at the XF, ZYT, CT, LTC, and LT sites (Fig. 11a). Of the sites, XF exhibited the highest $L_{\mathrm{OH}}$ of $16.2 \mathrm{~s}^{-1}$, followed by ZYT and CT with $L_{\mathrm{OH}}$ of 9.9 and $6.6 \mathrm{~s}^{-1}$, respectively. The XX site exhibited the lowest $L_{\mathrm{OH}}$ of $1.6 \mathrm{~s}^{-1}$, followed by the WQ and YST sites with $\mathrm{L}_{\mathrm{OH}}$ of 1.6 and $2.3 \mathrm{~s}^{-1}$, respectively. At the $\mathrm{CB}$, DHS, and QL sites, alkenes and OVOCs played a dominant role in $L_{\mathrm{OH}}$, accounting for $31.7 \%-50.8 \%$ and $26 \%$ $35.8 \%$ (Fig. 11a). For the gridded sampling sites, the overall $\mathrm{L}_{\mathrm{OH}}$ in Xi'an was significantly affected by alkenes, accounting for $45.4 \%-85.9 \%$. The top $10 \mathrm{VOC}$ species of $\mathrm{L}_{\mathrm{OH}}$ at the CB, DHS, QL, and grid sampling sites accounted for $69.2 \%$, $60.8 \%, 75.9 \%$, and $80.2 \%$ of the total $\mathrm{L}_{\mathrm{OH}}$, respectively $(\mathrm{Ta}-$ ble 2). Of these species, isoprene, acetaldehyde, ethylene, and 1-butene were the greatest contributors to total $\mathrm{LOH}_{\mathrm{OH}}$ in Xi' an, reaching $36.4 \%-63.0 \%$.

The $\mathrm{O}_{3}$ formation potentials of VOCs at the CB, DHS, and QL sites were 66.9, 74, and $35.6 \mathrm{ppb}$, respectively. The average VOC OFP at the 20 gridded sites was $53.9 \mathrm{ppb}$, and the high VOC OFPs were concentrated at the XF, ZYT, LTC, $\mathrm{CT}$, and HC sites (Fig. 11b). Of the sites, XF exhibited the highest OFP of $140.7 \mathrm{ppb}$, followed by ZYT and LTC with VOC OFPs of 87.9 and $75.7 \mathrm{ppb}$, respectively. The WQ site exhibited the lowest OFP of $21.9 \mathrm{ppb}$, followed by the XX and XHT sites with OFPs of 30.76 and $30.79 \mathrm{ppb}$, respectively. At the CB, DHS, and QL sites, alkenes and OVOCs played a dominant role in the OFP, accounting for $30.1 \%$ $40.2 \%$ and $31.1 \%-39.4 \%$, respectively (Fig. 11b). For the gridded sampling sites, the overall OFP in Xi' an was significantly affected by alkenes and aromatics, accounting for $39.7 \%-67.7 \%$ and $7.2 \%-23.2 \%$, respectively. The top 10 VOC OFP species at the CB, DHS, QL, and grid sampling sites accounted for $67.3 \%, 66.8 \%, 73.3 \%$, and $73.3 \%$ of the total OFP, respectively (Table 2). Of these species, ethylene, acetaldehyde, isoprene, and $m / p$-xylene were the greatest contributors in $\mathrm{Xi}$ ' an, reaching $44.2 \%-54.5 \%$.

\subsubsection{VOC-NO ${ }_{x}-\mathrm{O}_{3}$ sensitivity}

The relationship between the ozone production rates $(P$ $\left(\mathrm{O}_{3}\right)$ ), anthropogenic VOC (AVOC) reactivity, and $\mathrm{NO}_{x}$ reactivity of the CB, DHS, and QL sites during the observation period was shown in Fig. 12. The black curve in Fig. 12 

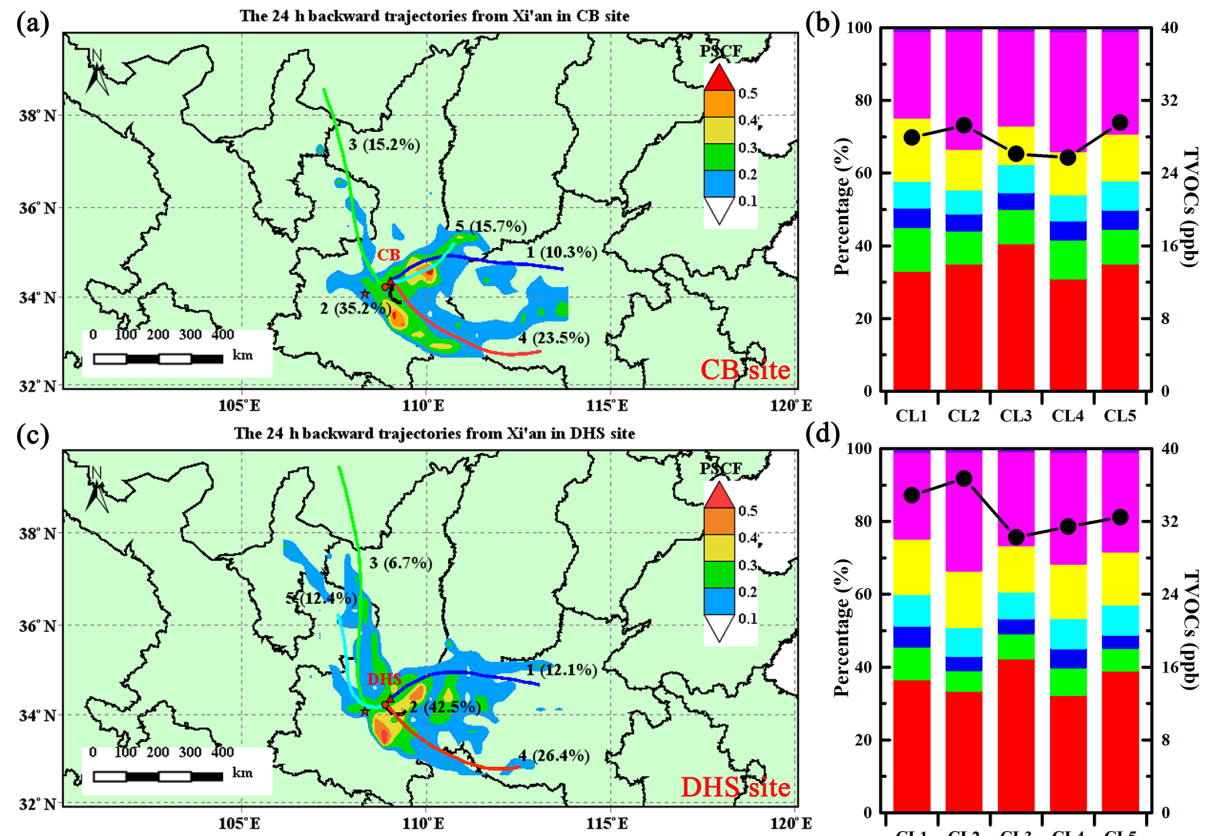

(d)
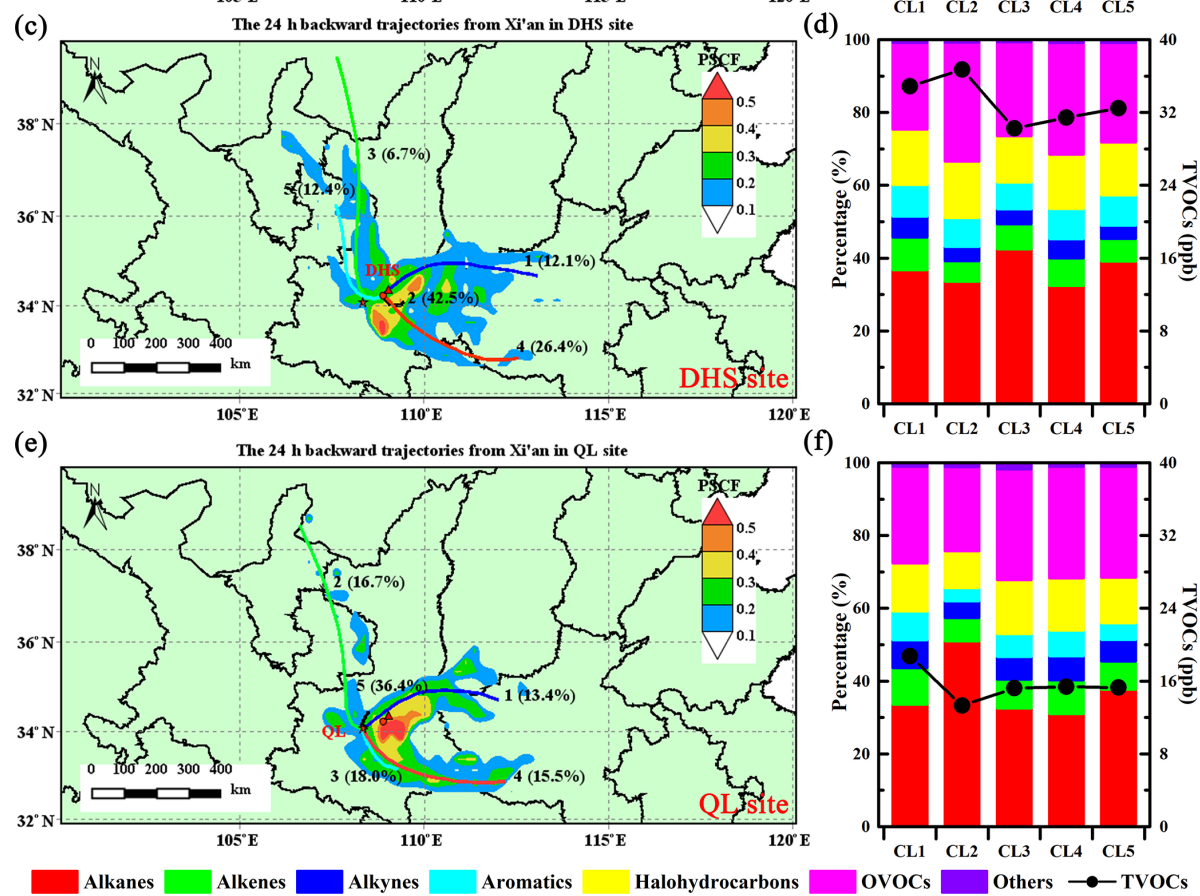

(f)

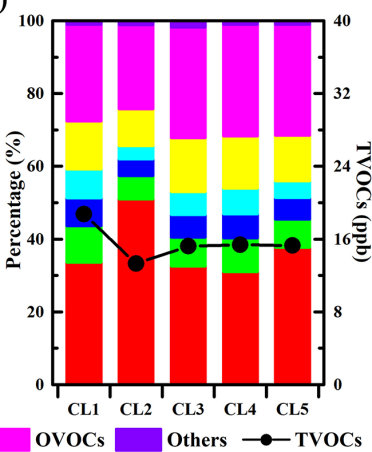

Figure 10. Backward trajectory cluster analysis (24 h) and PSCF analysis in the CB, DHS, and QL sites.

represents the $P\left(\mathrm{O}_{3}\right)$ contour, and the black straight line represents the connection line of the $P\left(\mathrm{O}_{3}\right)$ turning point (ridgeline), whose slope represents the photochemical parameter $k_{\mathrm{NO}_{x}} / k_{\mathrm{AVOCs}}$ (Jiang et al., 2018). When the site's $k_{\mathrm{NO}_{x}} / k_{\mathrm{AVOCs}}$ value is located above the ridgeline, it means that ozone formation is under VOC-limited regime; otherwise it means that ozone formation is under $\mathrm{NO}_{x}$-limited regime. It can be seen from Fig. 12 that the ozone generation of the QL site is located in the $\mathrm{NO}_{x}$-limited regime, and reducing $\mathrm{NO}_{x}$ can effectively control ozone generation. The ozone generation of the DHS site is located in the VOClimited regime, and reducing VOCs can effectively control ozone generation. However, the $\mathrm{CB}$ site is located in the transition regime between VOC- and $\mathrm{NO}_{x}$-limited regimes. Therefore, simultaneous reduction of $\mathrm{VOC}$ and $\mathrm{NO}_{x}$ concentration should be considered at the $\mathrm{CB}$ site to achieve the purpose of controlling $\mathrm{O}_{3}$.

\section{Conclusions}

In this study, a campaign of field observations and VOC grid sampling was conducted in Xi'an from 20 June to 20 July 2019. During the observation period, the average VOC concentrations at the CB, DHS, QL, and gridded sampling sites were $27.8 \pm 8.9,33.8 \pm 10.5,15.5 \pm 5.8$, and $29.1 \pm 8.4 \mathrm{ppb}$, respectively. Overall, the concentrations of VOCs in the Xi'an urban sites were approximately twice those of the rural sites. Due to a lower diffusion capacity and higher conversion capacity, the $\mathrm{O}_{3}$ concentration in Xi' an urban areas (CB and DHS) often exceeded the national hourly standard of $200 \mu \mathrm{g} / \mathrm{m}^{3}$ (approximately $101.9 \mathrm{ppb}$ ). In terms of the composition of VOCs at each site, alkanes and OVOCs were dominant in the VOC concentration, accounting for $25.7 \%-39.7 \%$ and $22.8 \%-47.4 \%$ of the TVOCs, respectively.

The PMF results demonstrated that vehicle exhaust, industry, combustion, paint solvent usage, and aging are the primary sources of VOCs in Xi'an. Of the sources, vehi- 
Table 2. Top 10 VOC concentration, $L_{\mathrm{OH}}$, and OFP species in the CB, DHS, QL, and grid sampling sites.

\begin{tabular}{|c|c|c|c|c|c|c|c|}
\hline Site & Rank & Species & $\begin{array}{r}\text { Concentration } \\
(\mathrm{ppb})\end{array}$ & Species & $\begin{array}{r}L_{\mathrm{OH}} \\
\left(\times 10^{-1} / \mathrm{s}\right)\end{array}$ & Species & $\begin{array}{l}\text { OFP } \\
(\mathrm{ppb})\end{array}$ \\
\hline \multirow[t]{10}{*}{$\mathrm{CB}$} & 1 & Acetone & 4.9 & Isoprene & 13.8 & Ethylene & 11.8 \\
\hline & 2 & Ethane & 3.0 & Acetaldehyde & 5.8 & Acetaldehyde & 10.2 \\
\hline & 3 & Propane & 1.9 & Ethylene & 2.7 & Isoprene & 6.0 \\
\hline & 4 & Acetaldehyde & 1.6 & $m$ / p-Xylene & 2.2 & $m / p$-Xylene & 3.8 \\
\hline & 5 & Ethyne & 1.4 & trans-2-Butene & 2.0 & Methyl vinyl ketone & 2.6 \\
\hline & 6 & Ethylene & 1.3 & 1-Butene & 1.8 & 1-Butene & 2.3 \\
\hline & 7 & $n$-Butane & 1.3 & Propanal & 1.4 & Propene & 2.2 \\
\hline & 8 & Dichloromethane & 1.2 & $n$-Hexanal & 1.4 & Propanal & 2.1 \\
\hline & 9 & Isobutane & 1.0 & 1-Hexene & 1.4 & Toluene & 2.1 \\
\hline & 10 & Isopentane & 0.9 & Methyl vinyl ketone & 1.3 & trans-2-Butene & 1.9 \\
\hline \multirow[t]{10}{*}{ DHS } & 1 & Acetone & 5.6 & Isoprene & 7.0 & Ethylene & 12.9 \\
\hline & 2 & Ethane & 3.9 & Acetaldehyde & 6.6 & Acetaldehyde & 11.8 \\
\hline & 3 & Propane & 2.1 & Ethylene & 3.0 & $m / p$-Xylene & 5.0 \\
\hline & 4 & Acetaldehyde & 1.8 & $m$ / p-Xylene & 3.0 & Methyl vinyl ketone & 4.0 \\
\hline & 5 & Dichloromethane & 1.7 & Methyl vinyl ketone & 2.0 & Toluene & 3.4 \\
\hline & 6 & $n$-Butane & 1.6 & Propanal & 1.6 & Isoprene & 3.0 \\
\hline & 7 & Ethyne & 1.5 & Propene & 1.6 & Propene & 2.9 \\
\hline & 8 & Ethylene & 1.4 & Styrene & 1.6 & Propanal & 2.4 \\
\hline & 9 & Isopentane & 1.0 & Dodecane & 1.4 & Acetone & 2.0 \\
\hline & 10 & Freon 11 & 0.9 & Methacrolein & 1.3 & $o$-Xylene & 2.0 \\
\hline \multirow[t]{10}{*}{ QL } & 1 & Ethane & 2.2 & Isoprene & 6.7 & Acetaldehyde & 8.7 \\
\hline & 2 & Acetone & 2.1 & Acetaldehyde & 4.9 & Ethylene & 6.6 \\
\hline & 3 & Propane & 1.4 & Ethylene & 1.5 & Isoprene & 2.9 \\
\hline & 4 & Acetaldehyde & 1.3 & Propene & 1.0 & Propene & 1.8 \\
\hline & 5 & Ethyne & 1.0 & $n$-Hexanal & 0.9 & Methyl vinyl ketone & 1.3 \\
\hline & 6 & $n$-Butane & 0.7 & $m$ / p-Xylene & 0.7 & $m / p$-Xylene & 1.2 \\
\hline & 7 & Ethylene & 0.7 & 1-Butene & 0.7 & Ethyne & 0.9 \\
\hline & 8 & Freon 11 & 0.7 & Methyl vinyl ketone & 0.6 & 1-Butene & 0.9 \\
\hline & 9 & Dichloromethane & 0.5 & Methacrolein & 0.6 & Propanal & 0.9 \\
\hline & 10 & Isopentane & 0.3 & Propanal & 0.6 & $n$-Butane & 0.9 \\
\hline \multirow[t]{10}{*}{ Xi'an } & 1 & Acetone & 6.6 & Isoprene & 27.1 & Isoprene & 11.7 \\
\hline & 2 & Ethane & 3.4 & Ethylene & 2.4 & Ethylene & 10.1 \\
\hline & 3 & Propane & 2.1 & 1-Butene & 2.1 & $m$ / p-Xylene & 2.9 \\
\hline & 4 & $n$-Butane & 1.3 & $m$ / p-Xylene & 1.7 & Propene & 2.9 \\
\hline & 5 & Ethyne & 1.3 & Propene & 1.6 & 1-Butene & 2.6 \\
\hline & 6 & Isopentane & 1.2 & MTBE & 1.4 & Acetone & 2.4 \\
\hline & 7 & Ethylene & 1.1 & Acrolein & 1.2 & Toluene & 1.9 \\
\hline & 8 & Isoprene & 1.1 & Isopentane & 1.0 & Acrolein & 1.8 \\
\hline & 9 & Dichloromethane & 0.8 & trans-2-Butene & 0.9 & Isopentane & 1.7 \\
\hline & 10 & Freon 11 & 0.7 & $n$-Butane & 0.8 & $n$-Butane & 1.5 \\
\hline
\end{tabular}

cle exhaust was the primary source of VOC emissions in $\mathrm{Xi}$ 'an, and the contributions of vehicle exhaust to the VOCs at the CB, DHS, and QL sites were $41.3 \%, 30.6 \%$, and $23.6 \%-41.4 \%$, respectively. In urban areas, industrial emissions were the second-largest source of VOC emissions, accounting for $29.7 \%$ and $30.6 \%$ at the CB and DHS sites, respectively. However, the contribution of aging sources was greater in rural areas, accounting for $19.2 \%$ at the QL site.

Based on the $24 \mathrm{~h}$ backward trajectories and PSCF analysis for Xi'an, in the urban areas, the VOC concentration was significantly affected by the southeast trajectory, and the high PSCF values were primarily observed to the east and south of Xi'an. In rural areas, the VOC concentration was significantly affected by the northeast trajectory, and the high PSCF values were primarily observed to the east of Xi'an. The highest PSCF values appeared in the area near the CB, DHS, and QL sites, which indicates that Xi' an has a strong local source.

In Xi'an, alkenes, aromatics, and OVOCs played a dominant role in secondary transformation. Isoprene, acetalde- 
Table 3. Air mass cluster analysis results for the CB, DHS, and QL sites.

\begin{tabular}{lrlrrrr}
\hline Site & Cluster & Air mass origins & $\begin{array}{r}\text { Ratio } \\
(\%)\end{array}$ & $\begin{array}{r}\text { TVOCs } \\
(\mathrm{ppb})\end{array}$ & $\begin{array}{r}\text { P_Ratio } \\
(\%)\end{array}$ & $\begin{array}{r}\text { P_TVOCs } \\
(\mathrm{ppb})\end{array}$ \\
\hline \multirow{2}{*}{ CB } & 1 & East & 10.3 & 27.9 & 8.4 & 38.3 \\
& 2 & Southeast & 35.2 & 29.3 & 42.8 & 39.6 \\
& 3 & Northwest (LDT) & 15.2 & 26.1 & 8.4 & 41.5 \\
& 4 & Southeast (M-LDT) & 23.5 & 25.7 & 18.1 & 40.5 \\
& 5 & Northeast & 15.7 & 29.5 & 22.3 & 40.3 \\
\hline \multirow{2}{*}{ DHS } & 1 & East & 12.1 & 34.9 & 11.9 & 45.2 \\
& 2 & Southeast & 42.5 & 36.7 & 58.5 & 48.2 \\
& 3 & Northwest (LDT) & 6.7 & 30.2 & 4.5 & 57.9 \\
& 4 & Southeast (M-LDT) & 26.4 & 31.4 & 14.8 & 45.2 \\
& 5 & Northwest & 12.4 & 32.5 & 10.2 & 48.3 \\
\hline \multirow{2}{*}{ QL } & 1 & East & 13.4 & 18.7 & 20.0 & 23.7 \\
& 2 & Northwest (LDT) & 16.7 & 13.3 & 9.1 & 22.7 \\
& 3 & Southeast & 18 & 15.2 & 17.1 & 22.9 \\
& 4 & Southeast (M-LDT) & 15.5 & 15.4 & 19.4 & 23.8 \\
& 5 & Northeast & 36.4 & 15.3 & 34.3 & 23.3 \\
\hline
\end{tabular}

LDT means long-distance trajectory. M-LDT means medium-long-distance trajectory. P Ratio means the proportions of the pollution trajectories in each type of clustering trajectory. P_TVOCs means the average TVOC concentration of the pollution trajectories.

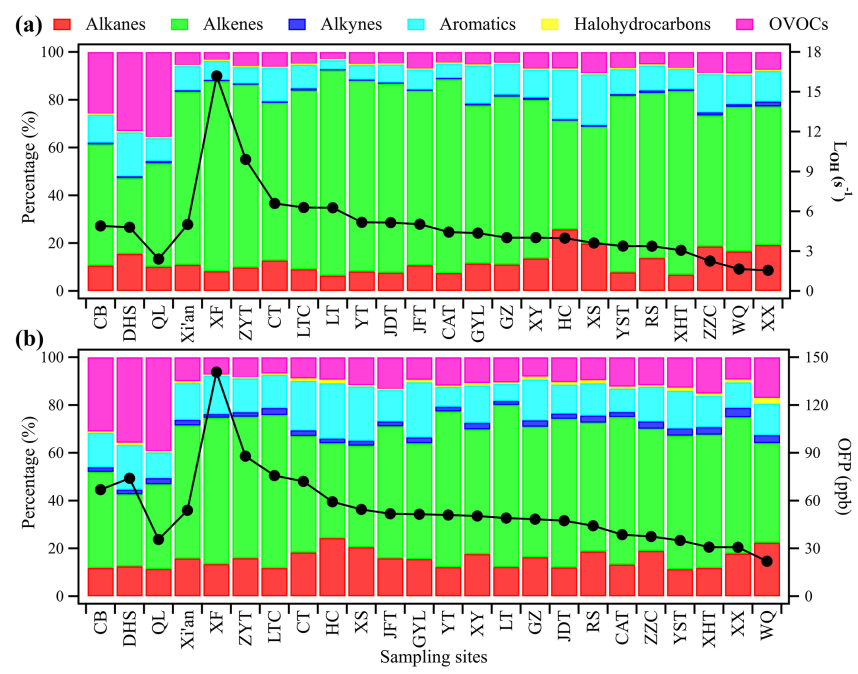

Figure 11. Contributions of different groups of VOCs to (a) $\mathrm{L}_{\mathrm{OH}}$ and (b) OFP in different sites in Xi'an.

hyde, ethylene, and 1-butene were the greatest contributors to $\mathrm{L}_{\mathrm{OH}}$ in $\mathrm{Xi}$ 'an, reaching $36.4 \%-63.0 \%$. Ethylene, acetaldehyde, isoprene, and $m / p$-xylene were the greatest contributors to OFP in $\mathrm{Xi}^{\prime}$ an, reaching $44.2 \%-54.5 \%$. These are the major species of concern for reducing $\mathrm{O}_{3}$ pollution in Xi' an. The VOC $-\mathrm{NO}_{x}-\mathrm{O}_{3}$ sensitivity analysis results showed that the ozone generation of the DHS site is located in the VOClimited regime, of $\mathrm{CB}$ in the transition regime between VOCand $\mathrm{NO}_{x}$-limited regimes, and of QL sites in the $\mathrm{NO}_{x}$-limited regime. Therefore, reducing VOC concentration at the DHS

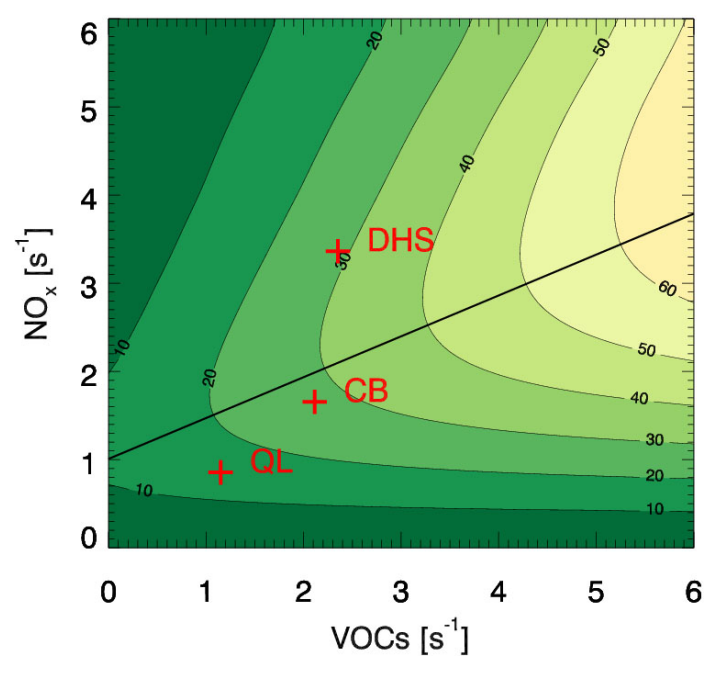

Figure 12. The ozone production rate $\left(P\left(\mathrm{O}_{3}\right)\right)$ contour diagram versus anthropogenic VOCs (AVOCs) and $\mathrm{NO}_{x}$ using the empirical kinetic modeling approach at CB, DHS, and QL sites.

site, reducing VOC and $\mathrm{NO}_{x}$ concentration at $\mathrm{CB}$ site, and reducing $\mathrm{NO}_{x}$ concentration at QL site can effectively control ozone generation.

Data availability. The underlying research data can be accessed upon contact with the corresponding author (Xin Li: li_xin@pku.edu.cn). 
Supplement. The supplement related to this article is available online at: https://doi.org/10.5194/acp-21-4939-2021-supplement.

Author contributions. XL and YZ designed the study. MS and XL analyzed the data and wrote the paper. XL, LZ, HD, KL, SC, JC, and NZ planned the locations of field observations and VOC grid sampling sites and built field observations sites. MS, SY, XY, YY, and $\mathrm{SZ}$ contributed to field observations and preprocessed data. KL, QC, and XY contributed to VOC grid sampling. MS and XL contributed to the revision of the paper. All authors contributed to the discussion and improvement of the paper.

Competing interests. The authors declare that they have no conflict of interest.

Acknowledgements. This work was supported by the National Natural Science Foundation of China (91644108 and 91844301) and by the National Key R\&D Program of China (2017YFC0209400).

Financial support. This research has been supported by the National Natural Science Foundation of China (grant no. 91644108), the National Natural Science Foundation of China (grant no. 91844301), and the National Key R\&D Program of China (grant no. 2017YFC0209400).

Review statement. This paper was edited by Aijun Ding and reviewed by three anonymous referees.

\section{References}

Ahmad, W., Coeur, C., Tomas, A., Fagniez, T., Brubach, J. B., and Cuisset, A.: Infrared spectroscopy of secondary organic aerosol precursors and investigation of the hygroscopicity of SOA formed from the $\mathrm{OH}$ reaction with guaiacol and syringol, Appl. Opt., 56, E116, https://doi.org/10.1364/AO.56.00E116, 2017.

An, J. L., Wang, J. X., Zhang, Y. X., and Zhu, B.: Source Apportionment of Volatile Organic Compounds in an Urban Environment at the Yangtze River Delta, China, Arch. Environ. Con. Tox., 72, 335-348, https://doi.org/10.1007/s00244-017-0371-3, 2017.

Ashbaugh, L. L., Malm, W. C., and Sadeh, W. Z.: A residence time probability analysis of sulfur concentrations at Grand Canyon National Park, Atmos. Environ., 19, 1263-1270, https://doi.org/10.1016/0004-6981(85)90256-2, 1985.

Birdsall, A. W. and Elrod, M. J.: Comprehensive NO-Dependent Study of the Products of the Oxidation of Atmospherically Relevant Aromatic Compounds, J. Phys. Chem. A., 115, 5397-5407, https://doi.org/10.1021/jp2010327, 2011.

Blake, D. R. and Rowland, F. S.: Urban Leakage of Liquefied Petroleum Gas and its Impact on Mexico-City Air-Quality, Science, 269, 953-956, https://doi.org/10.1126/science.269.5226.953, 1995.
Brown, S. G., Eberly, S., Paatero, P., and Norris, G. A.: Methods for estimating uncertainty in PMF solutions: Examples with ambient air and water quality data and guidance on reporting PMF results, Sci. Total. Environ., 518, 626-635, https://doi.org/10.1016/j.scitotenv.2015.01.022, 2015.

Cai, C., Geng, F., Tie, X., Yu, Q., and Junlin, A.: Characteristics and Source Apportionment of VOCs Measured in Shanghai, China, Atmos. Environ., 44, 5005-5014, https://doi.org/10.1016/j.atmosenv.2010.07.059, 2010.

Carter, W. P. L.: Development of the SAPRC-07 chemical mechanism, Atmos. Environ., 44, 5324-5335, https://doi.org/10.1016/j.atmosenv.2010.01.026, 2010.

Cuisset, A., Coeur, C., Mouret, G., Ahmad, W., Tomas, A., and Pirali, O.: Infrared spectroscopy of methoxyphenols involved as atmospheric secondary organic aerosol precursors: Gas-phase vibrational cross-sections, J. Quant. Spectrosc. Ra., 179, 51-58, https://doi.org/10.1016/j.jqsrt.2016.03.020, 2016.

Dai, P., Ge, Y., Lin, Y., Su, S., and Liang, B.: Investigation on characteristics of exhaust and evaporative emissions from passenger cars fueled with gasoline/methanol blends, Fuel, 113, 10-16, https://doi.org/10.1016/j.fuel.2013.05.038, 2013.

Deng, C. X., Jin, Y. J., Zhang, M., Liu, X. W., and Yu, Z. M.: Emission Characteristics of VOCs from On-Road Vehicles in an Urban Tunnel in Eastern China and Predictions for 2017-2026, Aerosol Air Qual. Res., 18, 3025-3034, https://doi.org/10.4209/aaqr.2018.07.0248, 2018.

Derstroff, B., Hüser, I., Bourtsoukidis, E., Crowley, J. N., Fischer, H., Gromov, S., Harder, H., Janssen, R. H. H., Kesselmeier, J., Lelieveld, J., Mallik, C., Martinez, M., Novelli, A., Parchatka, U., Phillips, G. J., Sander, R., Sauvage, C., Schuladen, J., Stönner, C., Tomsche, L., and Williams, J.: Volatile organic compounds (VOCs) in photochemically aged air from the eastern and western Mediterranean, Atmos. Chem. Phys., 17, 9547-9566, https://doi.org/10.5194/acp-17-9547-2017, 2017.

Dumanoglu, Y., Kara, M., Altiok, H., Odabasi, M., Elbir, T., and Bayram, A.: Spatial and seasonal variation and source apportionment of volatile organic compounds (VOCs) in a heavily industrialized region, Atmos. Environ., 98, 168-178, https://doi.org/10.1016/j.atmosenv.2014.08.048, 2014.

Goliff, W. S., Stockwell, W. R., and Lawson, C. V.: The regional atmospheric chemistry mechanism, version 2, Atmos. Environ., 68, 174-185, https://doi.org/10.1016/j.atmosenv.2012.11.038, 2013.

Gong, D., Wang, H., Zhang, S., Wang, Y., Liu, S. C., Guo, H., Shao, M., He, C., Chen, D., He, L., Zhou, L., Morawska, L., Zhang, Y., and Wang, B.: Low-level summertime isoprene observed at a forested mountaintop site in southern China: implications for strong regional atmospheric oxidative capacity, Atmos. Chem. Phys., 18, 14417-14432, https://doi.org/10.5194/acp-18-144172018, 2018.

Guenther, A. B., Zimmerman, P. R., Harley, P. C., Monson, R. K., and Fall, R.: Isoprene and monoterpene emission rate variability: Model evaluations and sensitivity analyses, J. Geophys. Res.Atmos., 98, 12609-12617, https://doi.org/10.1029/93JD00527, 1993.

Guenther, A. B., Jiang, X., Heald, C. L., Sakulyanontvittaya, T., Duhl, T., Emmons, L. K., and Wang, X.: The Model of Emissions of Gases and Aerosols from Nature version 2.1 (MEGAN2.1): an extended and updated framework for mod- 
eling biogenic emissions, Geosci. Model Dev., 5, 1471-1492, https://doi.org/10.5194/gmd-5-1471-2012, 2012.

Guo, H., Cheng, H. R., Ling, Z. H., Louie, P. K. K., and Ayoko, G. A.: Which emission sources are responsible for the volatile organic compounds in the atmosphere of Pearl River Delta?, J. Hazard. Mater., 188, 116-124, https://doi.org/10.1016/j.jhazmat.2011.01.081, 2011.

He, Q., Yan, Y., Li, H., Zhang, Y., Chen, L., and Wang, Y.: Characteristics and reactivity of volatile organic compounds from noncoal emission sources in China, Atmos. Environ., 115, 153-162, https://doi.org/10.1016/j.atmosenv.2015.05.066, 2015.

He, Z., Wang, X., Ling, Z., Zhao, J., Guo, H., Shao, M., and Wang, Z.: Contributions of different anthropogenic volatile organic compound sources to ozone formation at a receptor site in the Pearl River Delta region and its policy implications, Atmos. Chem. Phys., 19, 8801-8816, https://doi.org/10.5194/acp19-8801-2019, 2019.

Ho, K. F., Lee, S. C., Ho, W. K., Blake, D. R., Cheng, Y., Li, Y. S., Ho, S. S. H., Fung, K., Louie, P. K. K., and Park, D.: Vehicular emission of volatile organic compounds (VOCs) from a tunnel study in Hong Kong, Atmos. Chem. Phys., 9, 7491-7504, https://doi.org/10.5194/acp-9-7491-2009, 2009.

Hong, Z., Li, M., Wang, H., Xu, L., Hong, Y., Chen, J., Chen, J., Zhang, H., Zhang, Y., Wu, X., Hu, B., and Li, M.: Characteristics of atmospheric volatile organic compounds (VOCs) at a mountainous forest site and two urban sites in the southeast of China, Sci. Total. Environ., 657, 1491-1500, https://doi.org/10.1016/j.scitotenv.2018.12.132, 2019.

Huang, R. J., Zhang, Y. L., Bozzetti, C., Ho, K. F., Cao, J. J., Han, Y. M., Daellenbach, K. R., Slowik, J. G., Platt, S. M., Canonaco, F., Zotter, P., Wolf, R., Pieber, S. M., Bruns, E. A., Crippa, M., Ciarelli, G., Piazzalunga, A., Schwikowski, M., Abbaszade, G., Schnelle-Kreis, J., Zimmermann, R., An, Z. S., Szidat, S., Baltensperger, U., El Haddad, I., and Prevot, A. S. H.: High secondary aerosol contribution to particulate pollution during haze events in China, Nature, 514, 218-222, https://doi.org/10.1038/nature13774, 2014.

Huang, Y. S. and Hsieh, C. C.: Ambient volatile organic compound presence in the highly urbanized city: source apportionment and emission position, Atmos. Environ., 206, 45-59, https://doi.org/10.1016/j.atmosenv.2019.02.046, 2019.

Jia, C., Mao, X., Huang, T., Liang, X., Wang, Y., Shen, Y., Jiang, W., Wang, H., Bai, Z., Ma, M., Yu, Z., Ma, J., and Gao, H.: Non-methane hydrocarbons (NMHCs) and their contribution to ozone formation potential in a petrochemical industrialized city, Northwest China, Atmos. Res., 169, 225-236, https://doi.org/10.1016/j.atmosres.2015.10.006, 2016.

Jimenez, J. L., Canagaratna, M. R., Donahue, N. M., Prevot, A. S. H., Zhang, Q., Kroll, J. H., DeCarlo, P. F., Allan, J. D., Coe, H., Ng, N. L., Aiken, A. C., Docherty, K. S., Ulbrich, I. M., Grieshop, A. P., Robinson, A. L., Duplissy, J., Smith, J. D., Wilson, K. R., Lanz, V. A., Hueglin, C., Sun, Y. L., Tian, J., Laaksonen, A., Raatikainen, T., Rautiainen, J., Vaattovaara, P., Ehn, M., Kulmala, M., Tomlinson, J. M., Collins, D. R., Cubison, M. J., Dunlea, E. J., Huffman, J. A., Onasch, T. B., Alfarra, M. R., Williams, P. I., Bower, K., Kondo, Y., Schneider, J., Drewnick, F., Borrmann, S., Weimer, S., Demerjian, K., Salcedo, D., Cottrell, L., Griffin, R., Takami, A., Miyoshi, T., Hatakeyama, S., Shimono, A., Sun, J. Y., Zhang, Y. M., Dzepina, K., Kimmel,
J. R., Sueper, D., Jayne, J. T., Herndon, S. C., Trimborn, A. M., Williams, L. R., Wood, E. C., Middlebrook, A. M., Kolb, C. E., Baltensperger, U., and Worsnop, D. R.: Evolution of Organic Aerosols in the Atmosphere, Science, 326, 1525-1529, https://doi.org/10.1126/science.1180353, 2009.

Jiang, M., Lu, K., Su, R., Tan, Z., Wang, H., Li, L., Fu, Q., Zhai, C., Tan, Q., Yue, D., Chen, D., Wang, Z., Xie, S., Zeng, L., and Zhang, Y.: Ozone formation and key VOCs in typical Chinese city clusters, Chinese Sci. Bull., 63, 1130-1141, 2018.

Jin, X. and Holloway, T.: Spatial and temporal variability of ozone sensitivity over China observed from the Ozone Monitoring Instrument, J. Geophys. Res.-Atmos., 120, 7229-7246, https://doi.org/10.1002/2015jd023250, 2015.

Katzenstein, A. S., Doezema, L. A., Simpson, I. J., Balke, D. R., and Rowland, F. S.: Extensive regional atmospheric hydrocarbon pollution in the southwestern United States, P. Natl. Acad. Sci. USA., 100, 11975-11979, https://doi.org/10.1073/pnas.1635258100, 2003.

Li, J., Xie, S. D., Zeng, L. M., Li, L. Y., Li, Y. Q., and Wu, R. R.: Characterization of ambient volatile organic compounds and their sources in Beijing, before, during, and after Asia-Pacific Economic Cooperation China 2014, Atmos. Chem. Phys., 15, 7945-7959, https://doi.org/10.5194/acp-15-7945-2015, 2015.

Li, J., Zhai, C., Yu, J., Liu, R., Li, Y., Zeng, L., and Xie, S.: Spatiotemporal variations of ambient volatile organic compounds and their sources in Chongqing, a mountainous megacity in China, Sci. Total. Environ., 627, 1442-1452, https://doi.org/10.1016/j.scitotenv.2018.02.010, 2018.

Li, M., Shao, M., Li, L.-Y., Lu, S.-H., Chen, W.-T., and Wang, C.: Quantifying the ambient formaldehyde sources utilizing tracers, Chinese Chem. Lett., 25, 1489-1491, https://doi.org/10.1016/j.cclet.2014.07.001, 2014.

Li, M., Zhang, Q., Zheng, B., Tong, D., Lei, Y., Liu, F., Hong, C., Kang, S., Yan, L., Zhang, Y., Bo, Y., Su, H., Cheng, Y., and He, K.: Persistent growth of anthropogenic non-methane volatile organic compound (NMVOC) emissions in China during 19902017: drivers, speciation and ozone formation potential, Atmos. Chem. Phys., 19, 8897-8913, https://doi.org/10.5194/acp19-8897-2019, 2019.

Li, X.-H., Wang, S.-X., and Hao, J.-M.: Characteristics of Volatile Organic Compounds (VOCs) Emitted from Biofuel Combustion in China, Huanjing Kexue, 32, 3515-3521, 2011.

Ling, Z. H. and Guo, H.: Contribution of VOC sources to photochemical ozone formation and its control policy implication in Hong Kong, Environ. Sci. Pol., 38, 180-191, https://doi.org/10.1016/j.envsci.2013.12.004, 2014.

Ling, Z. H., Guo, H., Cheng, H. R., and Yu, Y. F.: Sources of ambient volatile organic compounds and their contributions to photochemical ozone formation at a site in the Pearl River Delta, southern China, Environ. Pollut., 159, 2310-2319, https://doi.org/10.1016/j.envpol.2011.05.001, 2011.

Ling, Z. H., He, Z. R., Wang, Z., Shao, M., and Wang, X. M.: Sources of methacrolein and methyl vinyl ketone and their contributions to methylglyoxal and formaldehyde at a receptor site in Pearl River Delta, J. Environ. Sci., 79, 1-10, https://doi.org/10.1016/j.jes.2018.12.001, 2019.

Liu, B., Liang, D., Yang, J., Dai, Q., Bi, X., Feng, Y., Yuan, J., Xiao, Z., Zhang, Y., and Xu, H.: Characterization and source apportionment of volatile organic compounds based on 1-year of 
observational data in Tianjin, China, Environ. Pollut., 218, 757769, https://doi.org/10.1016/j.envpol.2016.07.072, 2016a.

Liu, B. S., Liang, D. N., Yang, J. M., Dai, Q. L., Bi, X. H., Feng, Y. C., Yuan, J., Xiao, Z. M., Zhang, Y. F., and $\mathrm{Xu}, \mathrm{H} .:$ Characterization and source apportionment of volatile organic compounds based on 1-year of observational data in Tianjin, China, Environ. Pollut., 218, 757-769, https://doi.org/10.1016/j.envpol.2016.07.072, 2016b.

Liu, C., Ma, Z., Mu, Y., Liu, J., Zhang, C., Zhang, Y., Liu, P., and Zhang, H.: The levels, variation characteristics, and sources of atmospheric non-methane hydrocarbon compounds during wintertime in Beijing, China, Atmos. Chem. Phys., 17, 10633-10649, https://doi.org/10.5194/acp-17-10633-2017, 2017.

Liu, Y., Shao, M., Fu, L., Lu, S., Zeng, L. and Tang, D.: Source profiles of volatile organic compounds (VOCs) measured in China: Part I, Atmos. Environ., 42, 6247-6260, https://doi.org/10.1016/j.atmosenv.2008.01.070, 2008a.

Liu, Y., Shao, M., Lu, S., Chang, C.-C., Wang, J.-L., and Chen, G.: Volatile Organic Compound (VOC) measurements in the Pearl River Delta (PRD) region, China, Atmos. Chem. Phys., 8, 15311545, https://doi.org/10.5194/acp-8-1531-2008, 2008b.

Liu, Y., Song, M., Liu, X., Zhang, Y., Hui, L., Kong, L., Zhang, Y., Zhang, C., Qu, Y., An, J., Ma, D., Tan, Q., and Feng, M.: Characterization and sources of volatile organic compounds (VOCs) and their related changes during ozone pollution days in 2016 in Beijing, China, Environ. Pollut., 257, 113599, https://doi.org/10.1016/j.envpol.2019.113599, 2020.

Liu, Y., Wang, H., Jing, S., Gao, Y., Peng, Y., Lou, S., Cheng, T., Tao, S., Li, L., Li, Y., Huang, D., Wang, Q., and An, J.: Characteristics and sources of volatile organic compounds (VOCs) in Shanghai during summer: Implications of regional transport, Atmos. Environ., 215, 116902, https://doi.org/10.1016/j.atmosenv.2019.116902, 2019.

Lu, X., Hong, J., Zhang, L., Cooper, O. R., Schultz, M. G., Xu, X., Wang, T., Gao, M., Zhao, Y., and Zhang, Y.: Severe Surface Ozone Pollution in China: A Global Perspective, Environ. Sci. Technol. Lett., 5, 487-494, https://doi.org/10.1021/acs.estlett.8b00366, 2018.

Miller, S. L., Anderson, M. J., Daly, E. P., and Milford, J. B.: Source apportionment of exposures to volatile organic compounds. I. Evaluation of receptor models using simulated exposure data, Atmos. Environ., 36, 3629-3641, https://doi.org/10.1016/s13522310(02)00279-0, 2002.

Mo, Z. W., Shao, M., Liu, Y., Xiang, Y., Wang, M., Lu, S. H., Ou, J. M., Zheng, J. Y., Li, M., Zhang, Q., Wang, X. M., and Zhong, L. J.: Species-specified VOC emissions derived from a gridded study in the Pearl River Delta, China, Sci. Rep.-UK, 8, 2963, https://doi.org/10.1038/s41598-018-21296-y, 2018.

Mo, Z., Shao, M., and Lu, S.: Compilation of a source profile database for hydrocarbon and OVOC emissions in China, Atmos. Environ., 143, 209-217, https://doi.org/10.1016/j.atmosenv.2016.08.025, 2016.

Mo, Z., Shao, M., Lu, S., Qu, H., Zhou, M., Sun, J., and Gou, B.: Process-specific emission characteristics of volatile organic compounds (VOCs) from petrochemical facilities in the Yangtze River Delta, China, Sci. Total Environ., 533, 422-431, https://doi.org/10.1016/j.scitotenv.2015.06.089, 2015.

Niu, H., Mo, Z., Shao, M., Lu, S., and Xie, S.: Screening the emission sources of volatile organic compounds (VOCs) in
China by multi-effects evaluation, Front. Env. Sci. Eng., 10, 1, https://doi.org/10.1007/s11783-016-0828-z, 2016.

Pallavi, Sinha, B., and Sinha, V.: Source apportionment of volatile organic compounds in the northwest Indo-Gangetic Plain using a positive matrix factorization model, Atmos. Chem. Phys., 19, 15467-15482, https://doi.org/10.5194/acp-19-15467-2019, 2019.

Paatero, P. and Tapper, U.: Positive matrix factorization: A non-negative factor model with optimal utilization of error estimates of data values, Environmetrics, 5, 111-126, https://doi.org/10.1002/env.3170050203, 1994.

Peeters, J., Nguyen, T. L., and Vereecken, L.: HOx radical regeneration in the oxidation of isoprene, Phys. Chem. Chem. Phys., 11, 5935-5939, https://doi.org/10.1039/b908511d, 2009.

Polissar, A. V., Hopke, P. K., Paatero, P., Kaufmann, Y. J., Hall, D. K., Bodhaine, B. A., Dutton, E. G., and Harris, J. M.: The aerosol at Barrow, Alaska: long-term trends and source locations, Atmos. Environ., 33, 2441-2458, https://doi.org/10.1016/S13522310(98)00423-3, 1999.

Qiao, Y.-Z., Wang, H.-L., Huang, C., Chen, C.-H., Su, L.-Y., Zhou, M., Xu, H., Zhang, G.-F., Chen, Y.-R., Li, L., Chen, M.-H., and Huang, H.-Y.: Source Profile and Chemical Reactivity of Volatile Organic Compounds from Vehicle Exhaust, Huanjing Kexue, 33, 1071-1079, 2012.

Roberts, J. M., Fehsenfeld, F. C., Liu, S. C., Bollinger, M. J., Hahn, C., Albritton, D. L., and Sievers, R. E.: Measurements of Aromatic Hydrocarbon Ratios and $\mathrm{NO}_{x}$ Concentrations in the Rural Troposphere - Observation of Air-Mass Photochemical Aging and $\mathrm{NO}_{x}$ Removal, Atmos. Environ., 18, 2421-2432, https://doi.org/10.1016/0004-6981(84)90012-x, 1984.

Roger, A. and Janet, A.: Atmospheric degradation of volatile organic compounds, Chem. Rev., 103, 4605, https://doi.org/10.1021/cr0206420, 2003.

Schwantes, R. H., Schilling, K. A., McVay, R. C., Lignell, H., Coggon, M. M., Zhang, X., Wennberg, P. O., and Seinfeld, J. H.: Formation of highly oxygenated low-volatility products from cresol oxidation, Atmos. Chem. Phys., 17, 3453-3474, https://doi.org/10.5194/acp-17-3453-2017, 2017.

Shen, L., Wang, Z., Cheng, H., Liang, S., Xiang, P., Hu, K., Yin, T., and Yu, J.: A Spatial-Temporal Resolved Validation of Source Apportionment by Measurements of Ambient VOCs in Central China, Int. J. Env. Res. Pub. He., 17, 791, https://doi.org/10.3390/ijerph17030791, 2020.

Shi, J., Deng, H., Bai, Z., Kong, S., Wang, X., Hao, J., Han, X., and Ning, P.: Emission and profile characteristic of volatile organic compounds emitted from coke production, iron smelt, heating station and power plant in Liaoning Province, China, Sci. Total Environ., 515, 101-108, https://doi.org/10.1016/j.scitotenv.2015.02.034, 2015.

Song, M., Tan, Q., Feng, M., Qu, Y., Liu, X., An, J., and Zhang, Y.: Source Apportionment and Secondary Transformation of Atmospheric Nonmethane Hydrocarbons in Chengdu, Southwest China, J. Geophys. Res.-Atmos., 123, 9741-9763, https://doi.org/10.1029/2018jd028479, 2018.

Song, M. D., Liu, X. G., Zhang, Y. H., Shao, M., Lu, K. D., Tan, Q. W., Feng, M., and Qu, Y.: Sources and abatement mechanisms of VOCs in southern China, Atmos. Environ., 201, 28-40, https://doi.org/10.1016/j.atmosenv.2018.12.019, 2019. 
Song, Y., Shao, M., Liu, Y., Lu, S., Kuster, W., Goldan, P., and Xie, S.: Source apportionment of ambient volatile organic compounds in Beijing, Environ. Sci. Technol., 41, 4348-4353, https://doi.org/10.1021/es0625982, 2007.

Stavrakou, T., Müller, J.-F., Bauwens, M., De Smedt, I., Van Roozendael, M., Guenther, A., Wild, M., and Xia, X.: Isoprene emissions over Asia 1979-2012: impact of climate and land-use changes, Atmos. Chem. Phys., 14, 4587-4605, https://doi.org/10.5194/acp-14-4587-2014, 2014.

Su, Y.-C., Chen, W.-H., Fan, C.-L., Tong, Y.-H., Weng, T.H., Chen, S.-P., Kuo, C.-P., Wang, J.-L., and Chang, J.S.: Source Apportionment of Volatile Organic Compounds (VOCs) by Positive Matrix Factorization (PMF) supported by Model Simulation and Source Markers - Using Petrochemical Emissions as a Showcase, Environ. Pollut., 254, 112848, https://doi.org/10.1016/j.envpol.2019.07.016, 2019.

Sun, J., Wu, F., Hu, B., Tang, G., Zhang, J. and Wang, Y.: VOC characteristics, emissions and contributions to SOA formation during hazy episodes, Atmos. Environ., 141, 560-570, https://doi.org/10.1016/j.atmosenv.2016.06.060, 2016.

Sun, Y. L., Zhang, Q., Schwab, J. J., Yang, T., Ng, N. L., and Demerjian, K. L.: Factor analysis of combined organic and inorganic aerosol mass spectra from high resolution aerosol mass spectrometer measurements, Atmos. Chem. Phys., 12, 8537-8551, https://doi.org/10.5194/acp-12-8537-2012, 2012.

Tan, Z., Fuchs, H., Lu, K., Hofzumahaus, A., Bohn, B., Broch, S., Dong, H., Gomm, S., Häseler, R., He, L., Holland, F., Li, X., Liu, Y., Lu, S., Rohrer, F., Shao, M., Wang, B., Wang, M., Wu, Y., Zeng, L., Zhang, Y., Wahner, A., and Zhang, Y.: Radical chemistry at a rural site (Wangdu) in the North China Plain: observation and model calculations of $\mathrm{OH}, \mathrm{HO} 2$ and $\mathrm{RO} 2$ radicals, Atmos. Chem. Phys., 17, 663-690, https://doi.org/10.5194/acp17-663-2017, 2017.

Tan, Z., Lu, K., Jiang, M., Su, R., Dong, H., Zeng, L., Xie, S., Tan, Q., and Zhang, Y.: Exploring ozone pollution in Chengdu, southwestern China: A case study from radical chemistry to O3-VOC-NO ${ }_{x}$ sensitivity, Sci. Total Environ., 636, 775-786, https://doi.org/10.1016/j.scitotenv.2018.04.286, 2018.

Tsai, W. Y., Chan, L. Y., Blake, D. R., and Chu, K. W.: Vehicular fuel composition and atmospheric emissions in South China: Hong Kong, Macau, Guangzhou, and Zhuhai, Atmos. Chem. Phys., 6, 3281-3288, https://doi.org/10.5194/acp-6-3281-2006, 2006.

Uria-Tellaetxe, I. and Carslaw, D. C.: Conditional bivariate probability function for source identification, Environ. Model. Softw., 59, 1-9, https://doi.org/10.1016/j.envsoft.2014.05.002, 2014.

Wang, F., Chen, D. S., Cheng, S. Y., Li, J. B., Li, M. J., and Ren, Z. H.: Identification of regional atmospheric PM10 transport pathways using HYSPLIT, MM5-CMAQ and synoptic pressure pattern analysis, Environ. Model. Softw., 25, 927-934, https://doi.org/10.1016/j.envsoft.2010.02.004, 2010.

Wang, H., Qiao, Y., Chen, C., Lu, J., Dai, H., Qiao, L., Lou, S., Huang, C., Li, L., Jing, S., and Wu, J.: Source Profiles and Chemical Reactivity of Volatile Organic Compounds from Solvent Use in Shanghai, China, Aerosol Air Qual. Res., 14, 301-310, https://doi.org/10.4209/aaqr.2013.03.0064, 2014.

Wang, J., Jin, L., Gao, J., Shi, J., Zhao, Y., Liu, S., Jin, T., Bai, Z., and Wu, C.-Y.: Investigation of speciated VOC in gasoline vehicular exhaust under ECE and
EUDC test cycles, Sci. Total Environ., 445, 110-116, https://doi.org/10.1016/j.scitotenv.2012.12.044, 2013.

Wang, M., Chen, W., Lu, S., and Shao, M.: Ratios of Volatile Organic Compounds in Ambient Air of Various Cities of China, Huanjing, Kexue., 39, 4393-4399, https://doi.org/10.13227/j.hjkx.201801291, 2018.

Wang, M., Chen, W., Shao, M., Lu, S., Zeng, L., and Hu, M.: Investigation of carbonyl compound sources at a rural site in the Yangtze River Delta region of China, J. Environ. Sci., 28, 128136, https://doi.org/10.1016/j.jes.2014.12.001, 2015.

Wu, F. K., Yu, Y., Sun, J., Zhang, J. K., Wang, J., Tang, G. Q., and Wang, Y. S.: Characteristics, source apportionment and reactivity of ambient volatile organic compounds at Dinghu Mountain in Guangdong Province, China, Sci. Total. Environ., 548-549, 347359, https://doi.org/10.1016/j.scitotenv.2015.11.069, 2016a.

Wu, R., Bo, Y., Li, J., Li, L., Li, Y., and Xie, S.: Method to establish the emission inventory of anthropogenic volatile organic compounds in China and its application in the period 2008-2012, Atmos. Environ., 127, 244-254, https://doi.org/10.1016/j.atmosenv.2015.12.015, 2016b.

Yan, Y., Peng, L., Li, R., Li, Y., Li, L., and Bai, H.: Concentration, ozone formation potential and source analysis of volatile organic compounds (VOCs) in a thermal power station centralized area: A study in Shuozhou, China, Environ. Pollut., 223, 295-304, https://doi.org/10.1016/j.envpol.2017.01.026, 2017.

Yao, Y.-C., Tsai, J.-H., and Wang, I. T.: Emissions of gaseous pollutant from motorcycle powered by ethanol-gasoline blend, Appl. Energy, 102, 93-100, https://doi.org/10.1016/j.apenergy.2012.07.041, 2013.

Yao, Z., Shen, X., Ye, Y., Cao, X., Jiang, X., Zhang, Y., and He, K.: On-road emission characteristics of VOCs from diesel trucks in Beijing, China, Atmos. Environ., 103, 87-93, https://doi.org/10.1016/j.atmosenv.2014.12.028, 2015a.

Yao, Z., Wu, B., Shen, X., Cao, X., Jiang, X., Ye, Y., and He, K.: On-road emission characteristics of VOCs from rural vehicles and their ozone formation potential in Beijing, China, Atmos. Environ., 105, 91-96, https://doi.org/10.1016/j.atmosenv.2015.01.054, 2015b.

Yuan, B., Chen, W., Shao, M., Wang, M., Lu, S., Wang, B., Liu, Y., Chang, C.-C., and Wang, B.: Measurements of ambient hydrocarbons and carbonyls in the Pearl River Delta (PRD), China, Atmos. Res., 116, 93-104, https://doi.org/10.1016/j.atmosres.2012.03.006, 2012.

Yuan, B., Hu, W. W., Shao, M., Wang, M., Chen, W. T., Lu, S. H., Zeng, L. M., and Hu, M.: VOC emissions, evolutions and contributions to SOA formation at a receptor site in eastern China, Atmos. Chem. Phys., 13, 8815-8832, https://doi.org/10.5194/acp13-8815-2013, 2013.

Yuan, B., Shao, M., Lu, S., and Wang, B.: Source profiles of volatile organic compounds associated with solvent use in Beijing, China, Atmos. Environ., 44, 1919-1926, https://doi.org/10.1016/j.atmosenv.2010.02.014, 2010

Zhang, J., Wu, Y., Li, H., Ling, D., Han, K., Li, J., Hu, J., Wang, H., Zhang, M., and Wang, S.: Characteristics and source apportionment of ambient volatile organic compounds in autumn in Langfang development zones, Huanjing. Kexue., 39, 3186-3192, https://doi.org/10.19674/j.cnki.issn1000-6923.2019.0376, 2019.

Zhang, Y., Wang, X., Zhang, Z., Lu, S., Shao, M., Lee, F. S. C., and Yu, J.: Species profiles and normalized re- 
activity of volatile organic compounds from gasoline evaporation in China, Atmos. Environ., 79, 110-118, https://doi.org/10.1016/j.atmosenv.2013.06.029, 2013.

Zheng, H., Kong, S., Xing, X., Mao, Y., Hu, T., Ding, Y., Li, G., Liu, D., Li, S., and Qi, S.: Monitoring of volatile organic compounds (VOCs) from an oil and gas station in northwest China for 1 year, Atmos. Chem. Phys., 18, 4567-4595, https://doi.org/10.5194/acp-18-4567-2018, 2018.

Zheng, H., Kong, S. F., Yan, Y. Y., Chen, N., Yao, L. Q., Liu, X., Wu, F. Q., Cheng, Y., Niu, Z. Z., Zheng, S. R., Zeng, X., Yan, Q., Wu, J., Zheng, M. M., Liu, D. T., Zhao, D. L., and Qi, S. H.: Compositions, sources and health risks of ambient volatile organic compounds (VOCs) at a petrochemical industrial park along the Yangtze River, Sci. Total. Environ., 703, 135505, https://doi.org/10.1016/j.scitotenv.2019.135505, 2020.

Zheng, J., Yu, Y., Mo, Z., Zhang, Z., Wang, X., Yin, S., Peng, K., Yang, Y., Feng, X., and Cai, H.: Industrial sector-based volatile organic compound (VOC) source profiles measured in manufacturing facilities in the Pearl River Delta, China, Sci. Total Environ., 456, 127-136, https://doi.org/10.1016/j.scitotenv.2013.03.055, 2013.
Zhu, H., Wang, H., Jing, S., Wang, Y., Cheng, T., Tao, S., Lou, S., Qiao, L., Li, L., and Chen, J.: Characteristics and sources of atmospheric volatile organic compounds (VOCs) along the midlower Yangtze River in China, Atmos. Environ., 190, 232-240, https://doi.org/10.1016/j.atmosenv.2018.07.026, 2018.

Zhuang, Y., Cheng, C., Weng, X., Chen, J., Lv, X., Li, M., and Zhou, Z.: Characteristics and Source Apportionment of Atmospheric Volatile Organic Compounds During Emission Control Period in Xiamen, Chinese J. Anal. Chem., 47, 890-898, https://doi.org/10.19756/j.issn.0253-3820.181670, 2019. 